\title{
Coccolithophore responses to environmental variability in the South China Sea: species composition and calcite content
}

\author{
Xiaobo Jin ${ }^{1}$, Chuanlian Liu ${ }^{1}$, Alex J. Poulton ${ }^{2}$, Minhan Dai ${ }^{3}$, and Xianghui Guo ${ }^{3}$ \\ ${ }^{1}$ State Key Laboratory of Marine Geology, Tongji University, 200092 Shanghai, China \\ ${ }^{2}$ Ocean Biogeochemistry and Ecosystems, National Oceanography Centre, Southampton, SO14 3ZH, UK \\ ${ }^{3}$ State Key Laboratory of Marine Environmental Science, Xiamen University, 361005 Xiamen, China \\ Correspondence to: Chuanlian Liu (liucl@tongji.edu.cn)
}

Received: 5 March 2016 - Published in Biogeosciences Discuss.: 15 March 2016

Revised: 14 July 2016 - Accepted: 1 August 2016 - Published: 29 August 2016

\begin{abstract}
Coccolithophore contributions to the global marine carbon cycle are regulated by the calcite content of their scales (coccoliths) and the relative cellular levels of photosynthesis and calcification rates. All three of these factors vary between coccolithophore species and with response to the growth environment. Here, water samples were collected in the northern basin of the South China Sea (SCS) during summer 2014 in order to examine how environmental variability influenced species composition and cellular levels of calcite content. Average coccolithophore abundance and their calcite concentration in the water column were 11.82 cells $\mathrm{mL}^{-1}$ and $1508.3 \mathrm{pg} \mathrm{C} \mathrm{mL}^{-1}$, respectively, during the cruise. Water samples can be divided into three floral groups according to their distinct coccolithophore communities. The vertical structure of the coccolithophore community in the water column was controlled by the trophic conditions, which were regulated by mesoscale eddies across the SCS basin. The evaluation of coccolithophore-based calcite in the surface ocean also showed that three key species in the SCS (Emiliania huxleyi, Gephyrocapsa oceanica, Florisphaera profunda) and other larger, numerically rare species made almost equal contributions to total coccolith-based calcite in the water column. For Emiliania huxleyi biometry measurements, coccolith size positively correlated with nutrients (nitrate, phosphate), and it is suggested that coccolith length is influenced by light and nutrients through the regulation of growth rates. Larger-sized coccoliths were also linked statistically to low $\mathrm{pH}$ and calcite saturation states; however, it is not a simple cause and effect relationship, as carbonate chemistry was strongly co-correlated with the other key environmental factors (nutrients, light).
\end{abstract}

\section{Introduction}

Coccolithophores are an important component of marine phytoplankton communities, contributing globally to both the organic carbon pump (biological carbon pump) and the (calcium) carbonate (counter) pump. Coccolithophores may contribute 10 to $20 \%$ of total chlorophyll $a$, and primary production and 30 to $60 \%$ of calcium carbonate (calcite or particulate inorganic carbon) in the water column in nonbloom conditions (Poulton et al., 2006, 2007, 2010, 2014), although higher contributions of organic carbon (>40\%) do occur in coccolithophore blooms (Poulton et al., 2013). Coccolith-based calcite can contribute up to $80 \%$ to deepsea carbonate fluxes (Sprengel et al., 2000, 2002; Young and Ziveri, 2000). High concentrations of the cosmopolitan coccolithophore species Emiliania huxleyi can generate large quantities of cells and detached coccoliths (e.g., $\sim 2000$ cells $\mathrm{mL}^{-1}$ and $3 \times 10^{5}$ coccoliths $\mathrm{mL}^{-1}$; Balch et al., 1991), which are detectable from space (Cokacar et al., 2004; Raitsos et al., 2006); for example, the Great Calcite Belt in the Southern Hemisphere is attributed to high particulate inorganic carbon from coccolithophores (Balch et al., 2011, 2014). To assess the contribution of coccolithophores to the carbon cycle, two relevant issues are worthy of attention: (1) coccolithophore species composition and calcite concentration in the water column and (2) their calcification responses to oceanic environmental factors.

The South China Sea (SCS) is the largest marginal sea in the west Pacific Ocean, covering an area of $3.5 \times 10^{6} \mathrm{~km}^{2}$ (Wang et al., 2014). Phytoplankton production and surface circulation in the northern basin of the SCS are greatly in- 
fluenced by the East Asian monsoon system. In the northern part of SCS, during the summer season (June to August), the surface water is oligotrophic and well stratified, and a stable mixed layer is developed. The mean chlorophyll $a$ concentration and primary production in the euphotic zone is $0.08 \pm 0.03 \mathrm{mg} \mathrm{m}^{-3}$ and $<30 \mathrm{mg} \mathrm{C} \mathrm{m}^{-2} \mathrm{~d}^{-1}$, respectively (Chen, 2005; Chen et al., 2006), with the nitricline at a depth of $\sim 60 \mathrm{~m}$ (Chen et al., 2006). During the winter season (December to February), surface waters are productive and well mixed due to the strong seasonal wind stress. Mean chlorophyll $a$ concentrations and primary production are $0.65 \pm 0.17 \mathrm{mg} \mathrm{m}^{-3}$ and $550 \mathrm{mg} \mathrm{C} \mathrm{m}^{-2} \mathrm{~d}^{-1}$, respectively (Chen, 2005; Chen et al., 2006), with the nitricline much shallower at around 5 to $20 \mathrm{~m}$ (Chen et al., 2006). Some preliminary work on coccolithophore biogeography has been reported in the SCS (Okada and Honjo, 1975; Chen et al., 2007a; Sun et al., 2011); however, these studies are confined to surface waters or sporadic sampling sites and lack any coccolith weight estimation.

Mesoscale eddies are typical physical oceanographic features in the SCS (Wang et al., 2003) and significantly influence the structure of the upper water column. Cyclonic eddies in the SCS can cause the thermocline to shallow and thin, while anticyclonic eddies have the opposite effect (Chen et al., 2011). Eddy activity in the SCS is related to local wind stress curl, intrusion of the Kuroshio Current, and coastal baroclinic jets (Wang et al., 2003; Hu et al., 2011). Coldwater cyclonic eddies can elevate the nutricline into subsurface waters and drive enhanced phytoplankton production at levels exceeding those in the winter. For example, the average integrated primary production inside eddies in spring and in winter is 1090 and $550 \mathrm{mg} \mathrm{C} \mathrm{m}^{-2} \mathrm{~d}^{-1}$, respectively (Chen, 2005; Chen et al., 2007b). Modeling studies have reported that cyclonic eddies are significant nutrient sources fueling the biological carbon pump in the SCS (Xiu and Chai, 2011). Pigments determined by high-performance liquid chromatography have also shown that phytoplankton assemblages relate to mesoscale eddies in the SCS (Huang et al., 2010; Wang et al., 2016); however, how coccolithophore communities respond to these regular oceanographic phenomena is still unclear.

Decreasing ocean $\mathrm{pH}$ (termed ocean acidification), in response to increasing atmospheric and seawater $\mathrm{CO}_{2}$ levels, is a major concern for marine calcifiers such as coccolithophores, as lower $\mathrm{pH}$ levels (and calcium carbonate saturation levels, $\Omega_{\mathrm{C}}$ ) may lead to calcite dissolution and/or make the process of calcite formation (calcification) more difficult (Riebesell et al., 2000; Beaufort et al., 2011). Conflicting results concerning coccolithophore calcification have been reported from both experimental and field studies (e.g., Riebesell et al., 2000; Iglesias-Rodriguez et al., 2008; Riebesell and Tortell, 2011; Meyer and Riebesell, 2015). A recent study by Bach et al. (2015) found that laboratory findings could be reconciled when an optimum-type response to bicarbonate ion availability and $\mathrm{pH}$ was considered. In the field, different communities may respond to different combinations of elevated $\mathrm{pH}$ and/or nutrient availability, emphasizing the importance of species composition to community responses and to the multivariate nature of the growth environment (Poulton et al., 2011, 2014). Species-specific responses to ocean acidification are evident from laboratory work (Langer et al., 2006, 2009) and in the geological record (Gibbs et al., 2013; O'Dea et al., 2014), with regional oceanographic settings also having an important influence (Beaufort et al., 2011; Meier et al., 2014). Hence, it is necessary to understand how coccolith (e.g., E. huxleyi strains in the SCS) size and morphology respond to environmental factors in the oligotrophic and marginal SCS.

In the present study, we performed an in situ investigation of coccolithophores (species composition, coccolith biometry) in the upper water column of the SCS in relation to the prevailing environmental conditions. The aims of this research were (1) to examine coccolithophore biogeography more clearly alongside their calcite concentration in the upper water column and (2) to determine how coccolith morphology (i.e., E. huxleyi) responds to environmental variability (light, nutrients, and carbonate chemistry) in a lowlatitude marginal sea.

\section{Materials and methods}

\subsection{Field sampling}

A total of 72 water samples from 15 stations were collected during the R/V Dongfanghong II cruise of the National Science Foundation (2014). At most stations, five depths were sampled: $25,50,75,100$, and $150 \mathrm{~m}$ (Table 1 ). Water samples were not collected in the upper $5 \mathrm{~m}$ as this was extremely nutrient depleted, with especially low chlorophyll $a$ concentrations (http://oceancolor.gsfc.nasa.gov/cms/) in summer (Fig. 1). For each water sample, $3 \mathrm{~L}$ was collected via a conductivity-temperature-depth (CTD) rosette sampler and filtered through $0.45 \mu \mathrm{m}$ pore size $47 \mathrm{~mm}$ diameter nitrocellulose membrane filters (Sartorius ${ }^{\circledR}$ ) under gentle pressure. The filters were rinsed to remove residual saline seawater, dried on an electric heat platform $\left(65^{\circ} \mathrm{C}, 10-15 \mathrm{~min}\right)$ and then stored in Petri dishes wrapped with aluminum foil and stored frozen $\left(-20^{\circ} \mathrm{C}\right)$.

\subsection{Coccolithophore and coccolith counts}

A small piece $(\sim 0.5 \times 0.5 \mathrm{~cm})$ of each filter was cut out and mounted on glass slides using Norland Optical Adhesive (No. 74). Coccolithophore cell counts and species identification was undertaken using cross-polarized light microscopy (Olympus BX51). In samples with abundant coccolithophore cells, individual cells (coccospheres) were counted from at least 100 fields of view (FOVs, diameter of each FOV is $220 \mu \mathrm{m}$ ) up to a total of 150 to $400 \mathrm{coc}-$ cospheres. For samples with low abundance, around 50 ex- 

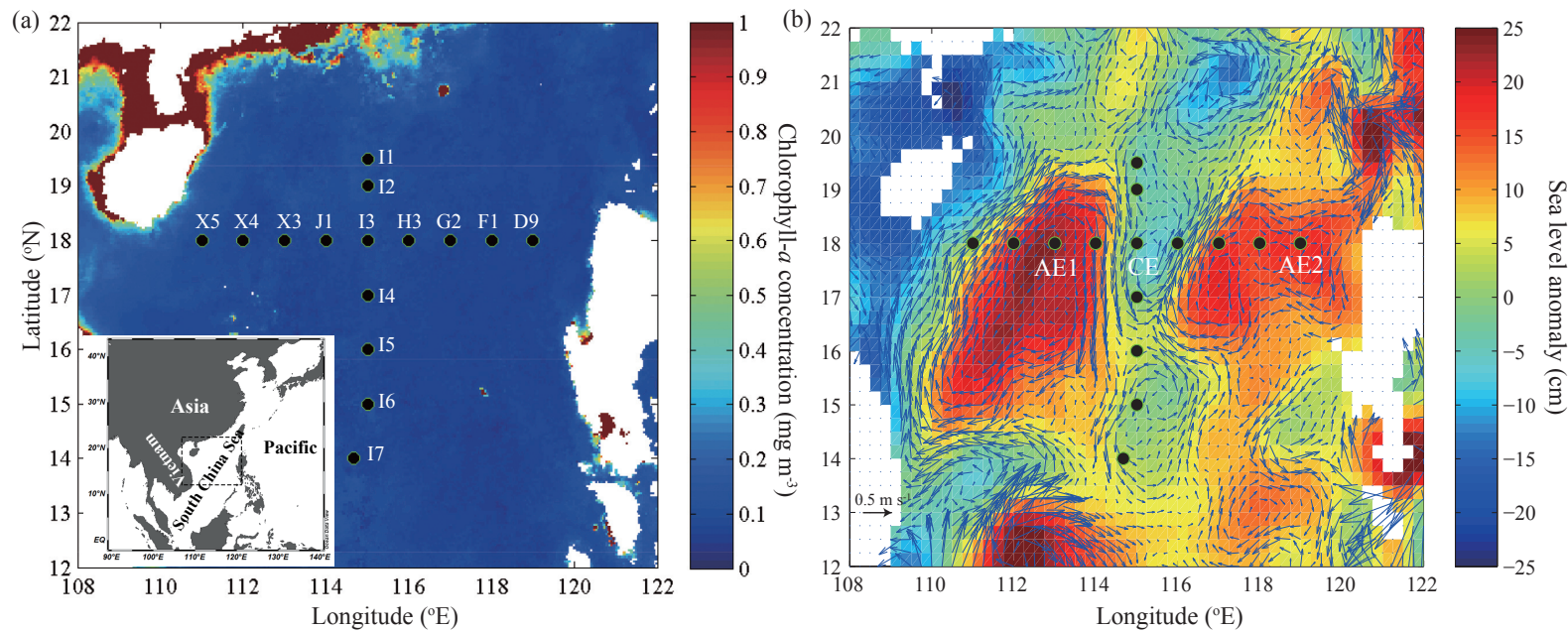

Figure 1. (a) Sampling stations in the South China Sea, superimposed on the Aqua-MODIS (4 km) monthly average (May to August 2014) surface chlorophyll $a\left(\mathrm{mg} \mathrm{m}^{-3}\right)$. (b) Map of sea level anomaly (SLA) and geostrophic flow on 28 June 2014. The positive SLA with clockwise flow indicates anticyclonic eddies (AEs), and the negative SLA with anticlockwise flow indicates cyclonic eddies (CEs).

Table 1. Sampling dates, location, depth, and mixed layer depth (MLD) at each station.

\begin{tabular}{llrrlr}
\hline Station & $\begin{array}{l}\text { Date (yyyy/m/dd) } \\
(\mathrm{GMT}+8)\end{array}$ & Longitude & Latitude & $\begin{array}{l}\text { Sampling depth } \\
(\mathrm{m})\end{array}$ & $\begin{array}{r}\text { MLD } \\
(\mathrm{m})\end{array}$ \\
\hline D9 & $2014 / 6 / 257: 11$ & 119 & 18 & $25,50,75,100,150$ & 34 \\
F1 & $2014 / 6 / 263: 38$ & 118 & 18 & $25,50,75,100,150$ & 24 \\
G2 & $2014 / 6 / 2614: 36$ & 117 & 18 & $25,45,75,100,150$ & 12 \\
H3 & $2014 / 6 / 2715: 08$ & 116 & 18 & $25,60,75,100,150$ & 11 \\
I1 & $2014 / 6 / 200: 52$ & 115 & 19.5 & $25,50,100$ & 16 \\
I2 & $2014 / 6 / 2020: 50$ & 115 & 19 & $25,50,75,100,150$ & 16 \\
I3 & $2014 / 6 / 299: 23$ & 115 & 18 & $25,50,75,100,150$ & 23 \\
J1 & $2014 / 6 / 2920: 35$ & 114 & 18 & $25,50,75,100,150$ & 26 \\
X3 & $2014 / 6 / 306: 58$ & 113 & 18 & $25,50,75,100,150$ & 30 \\
X4 & $2014 / 6 / 3018: 01$ & 112 & 18 & $25,50,75,100,150$ & 35 \\
X5 & $2014 / 7 / 15: 10$ & 111 & 18 & $25,50,75,100,150$ & 17 \\
I4 & $2014 / 7 / 98: 23$ & 115 & 17 & $25,50,75,100,150$ & 18 \\
I5 & $2014 / 7 / 91: 54$ & 115 & 16 & $25,50,75,100,150$ & $(<25)$ \\
I6 & $2014 / 7 / 817: 53$ & 115 & 15 & $25,50,75,100$ & $(>25)$ \\
I7 & $2014 / 7 / 722: 33$ & 114.67 & 14 & $25,50,75,100,150$ & 20 \\
\hline
\end{tabular}

tra FOVs were examined, which suggests a detection limit of $\sim 0.27$ cells $\mathrm{mL}^{-1}$ at a $95 \%$ probability level (Bollmann et al., 2002). For counts and morphological measurements of detached coccoliths, a second piece of each filter was cut out $(\sim 0.5 \times 0.5 \mathrm{~cm})$ and mounted on an aluminum stub with double-sided conductive carbon tape and coated with gold (see Poulton et al., 2011). A Leo 1450VP Scanning Electron Microscopy (Carl Zeiss) with SmartSEM (V5.1) software was then used to automatically capture images of consecutive FOVs from a $12 \times 12$ FOV (each FOV was $4.054 \times 10^{-3} \mathrm{~mm}^{2}$ ) grid at a magnification of $\times 5000$, providing 144 images for analyses of detached coccolith counting and biometry. Coccolithophore species identification by light microscopy and scanning electron microscopy (SEM) followed Frada et al. (2010), Young et al. (2003), and the Nannotax3 website (http://ina.tmsoc.org/Nannotax3/). Coccosphere and coccolith abundance was calculated using the following Eq. (1):

coccosphere or coccolith abundance

(cells coccoliths $\left.{ }^{-1} \mathrm{~mL}^{-1}\right)=N \times S /(A \times V)$,

where $N$ is the number of coccospheres or coccoliths counted, $S$ is the filtered area ( $45 \mathrm{~mm}$ diameter) on each filter, $A$ is the area inspected ( $A=$ number of FOV $\times$ area of $1 \mathrm{FOV})$, and $V$ is the filtered water volume $(\mathrm{mL})$. 


\subsection{Coccosphere and coccolith biometry and calcite estimates}

Two distinguishable morphotypes of E. huxleyi (type A and type C) were observed in the SEM images, with type A being the majority morphotype of total E. huxleyi cell counting. The type $\mathrm{C}$ coccospheres were only found sporadically in some samples. Hence, the measurements of E. huxleyi biometry including distal shield length (DSL) and coccospheres diameter (CD) were based only on morphotype $\mathrm{A}$ in this study. A total of 2560 E. huxleyi detached coccoliths (for DSL) and 102 intact coccospheres (for DSL and CD) were measured across the study sites.

In addition to $E$. huxleyi, coccolith lengths of all species were measured to estimate bulk coccolith calcite concentration in the water column. Individual coccolith calcite content (calcite mass) was calculated using Eq. (2) adapted from Young and Ziveri (2000):

$m\left(\mathrm{pgC}, \mathrm{CaCO}_{3}\right)=2.7 \times k_{\mathrm{s}} \times \mathrm{DSL}^{3}$,

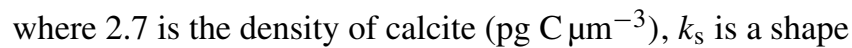
constant determined for different species (Young and Ziveri, 2000), and DSL is the distal shield length of each coccolith $(\mu \mathrm{m})$. For whole coccospheres, the calcite content was estimated by multiplying the calcite mass of a single coccolith (lying flat on the upper side of the coccosphere) with an estimate of the number of coccoliths in the coccosphere (e.g., 16 to 48 coccoliths in an E. huxleyi coccosphere in this study). Numbers of coccoliths per coccosphere in the present study were also estimated with reference to Boeckel and Baumann (2008). All the biometry work was carried out on the basis of SEM images using ImageJ software (http: //rsb.info.nih.gov/ij/), following Poulton et al. (2011).

Three coccolithophore species (Gladiolithus flabellatus, Calciosolenia murrayi, and Algirosphaera robusta) present in the SCS do not have $k_{\mathrm{s}}$ values in Young and Ziveri (2000) or in similar coccolith calcite estimates (e.g., Knappertsbusch and Brummer, 1995; Beaufort and Heussner, 1999). For the body coccolith of $G$. flabellatus, a $k_{\mathrm{s}}$ value is estimated as 0.0016, adjusted from Florisphaera profunda (0.04) and based on their similar rectangle shapes. For $C$. murrayi, the rhomboid-shaped coccosphere is dimorphic, having both body coccoliths and narrow coccoliths around the apical opening (Young et al., 2003). Body coccolith lengths in $C$. murrayi range from 2.2 to $2.6 \mu \mathrm{m}$, with the mean length / width ratio $\sim 3.045$ in our samples, and the thickness is about $0.2 \mu \mathrm{m}$ (from Malinverno, 2004). From these morphological parameters, the $k_{\mathrm{S}}$ value we estimated is 0.027 . For $A$. robusta, each coccolith contains two parts: a base and a protrusion. The former is similar to a small Syracosphaera coccolith, with a $k_{\mathrm{S}}$ value of 0.015 (Young and Ziveri, 2000) and for the latter $k_{\mathrm{s}}$ value we calculated a cylindroid-like volume which we estimated as 0.045. Combining these two estimates gave a $k_{\mathrm{s}}$ value of 0.06 for $A$. robusta in this study.

\subsection{Environmental parameters}

Seawater temperature, salinity, and chlorophyll fluorescence were taken from the CTD. For stations I4, I5, I6, and I7, CTD problems led to discontinuous temperature and salinity data. Mixed layer depths (MLDs) were taken as the depth where the temperature difference was $>0.5^{\circ} \mathrm{C}$ with respect to surface waters ( $<5 \mathrm{~m}$; Painter et al., 2010), while for stations I4 to I6, the MLDs were only roughly determined according to vertical temperature profiles (see Fig. 2b). Euphotic zone depth is defined as the depth to which $1 \%$ of surface irradiance penetrates. Photosynthetically active radiation (PAR) through the water column is calculated following Eq. (3):

$\mathrm{PAR}_{Z}=\mathrm{PAR}_{0} \times \exp \left(-K_{\mathrm{d}} \times Z\right)$,

where $K_{\mathrm{d}}$, the vertical diffuse attenuation coefficient, is estimated by the following Eq. (4) from Wei (2005):

$K_{\mathrm{d}}=0.027+0.252 \times c_{\mathrm{p}}$,

where $c_{\mathrm{p}}$ is the beam attenuation recorded by the CTD. Identification of eddy activity was according to the temperature sections (Fig. 2) and altimeter data on sea level anomalies (SLAs) and geostrophic flow from the AVISO website (http://www.aviso.altimetry.fr/en/home.html).

Macronutrient (nitrate + nitrite, phosphate) concentrations were determined immediately on board with colorimetric methods, using a Technicon AA3 Auto-Analyzer (BranLube). The detection limits for nitrate + nitrite and phosphate are 0.1 and $0.08 \mu \mathrm{mol} \mathrm{L}^{-1}$, respectively. Seawater carbonate parameters (total alkalinity $\left(A_{\mathrm{T}}\right)$ and dissolved inorganic carbon $\left(C_{\mathrm{T}}\right)$ ) were determined following the updated Joint Global Ocean Flux Study protocols (Dickson et al., 2007). Water samples for measurements were poisoned with saturated mercuric chloride solution and stored in the dark before analysis. $C_{\mathrm{T}}$ was measured on board within 2 days of sampling and $A_{\mathrm{T}}$ was measured within 2 months. $C_{\mathrm{T}}$ was measured by collecting and quantifying the $\mathrm{CO}_{2}$ released from the sample upon acidification with a nondispersive infrared detector (LI-COR ${ }^{\circledR} 7000$ ). $A_{\mathrm{T}}$ was measured by potentiometric Gran titration. The accuracies of the $A_{\mathrm{T}}$ and $C_{\mathrm{T}}$ measurements were calibrated against the certified reference materials provided by A. G. Dickson of the Scripps Institution of Oceanography. Carbonate ion concentration, carbonate calcium saturation $\left(\Omega_{\mathrm{C}}\right)$, and $\mathrm{pH}$ were calculated by $\mathrm{CO}_{2}$ SYS excel macro (Pierrot et al., 2006) from nutrients, $C_{\mathrm{T}}, A_{\mathrm{T}}$, temperature, and salinity.

\subsection{Statistical analysis}

Multivariate data analysis was performed to further examine the coccolithophore composition across the study sites using the PRIMER-E (v. 6.0) program (Clarke and Warwick, 2001). Before analysis, the sites of zero coccolithophore abundance and those at $150 \mathrm{~m}$ were removed and the absolute coccolithophore abundance data were then treated by 

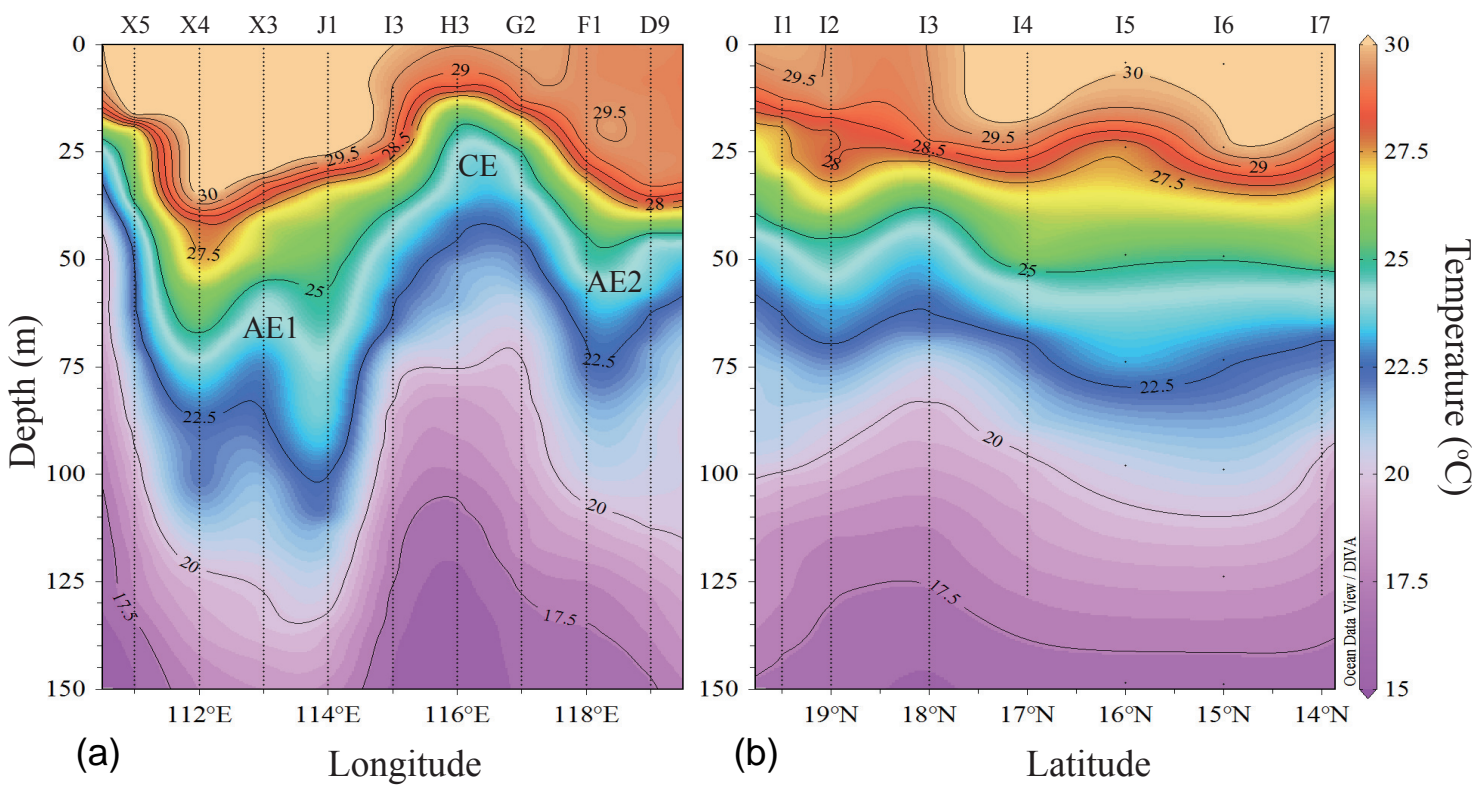

Figure 2. Temperature $\left({ }^{\circ} \mathrm{C}\right)$ profiles in zonal (a) and meridional (b) sections. Variation of isotherm indicates anticyclonic eddies (AEs) and cyclonic eddies (CEs), respectively. Profiles are drawn with Ocean Data View software (Schlitzer, 2015).

square-root transformation. With these abundance data, a Bray-Curtis similarity matrix was constructed and analyzed via hierarchical cluster analysis (HCA) together with nonmetric multidimensional scaling (nMDS).

Principal component analysis was also performed based on the $\mathrm{z}$-score normalized environmental parameters to evaluate the main controlling factors. Pearson's product-moment correlations and Spearman's rank correlation were used to examine potential relationships between coccolithophore data and environmental factors. One-way ANOVA was performed to assess the coccolith length differences between samples. These statistical analyses were carried out using the PAST software (Hammer et al., 2001).

\section{Results}

\subsection{Physicochemical settings}

A conspicuous deep chlorophyll $a$ maximum (DCM) was present throughout, ranging from $\sim 50$ to $75 \mathrm{~m}$ in depth (Fig. 3). Total nitrogen and phosphate concentrations were below the limit of quantitation in the upper $25 \mathrm{~m}$. A nitrogen concentration of $1 \mu \mathrm{mol} \mathrm{L}^{-1}$ was defined as the threshold of the nitricline and also the nutricline (Mullin, 1998), which was within the range of $<50$ to $75 \mathrm{~m}$ (Fig. 3). All stations were stratified, with shallow mixed layers, ranging from 11 to $35 \mathrm{~m}$. According to the vertical temperature profiles, SLA map, and geostrophic flows (Figs. 1b and 2), two anticyclonic eddies (labeled herein as AEs) and one cyclonic eddy (CE) were present across the $18^{\circ} \mathrm{N}$ section, with stations $\mathrm{X} 4, \mathrm{X} 3$, and J1 located in AE1, F1, and D9 located in AE2, and I3 and $\mathrm{H} 3$ located in CE. The nutricline and DCM changed with the variability of oceanographic settings; e.g., they shallowed in the CE stations and deepened in the AE stations (Fig. 3). Euphotic zone depths ranged from 90 to $100 \mathrm{~m}$, except at stations I1 and I2, where the euphotic zone depth was $\sim 70 \mathrm{~m}$. The detailed SLA and geostrophic flow maps during sampling dates can be found in the Supplement.

\subsection{Coccolithophore community}

The average coccolithophore cell abundance was 11.82 cells $\mathrm{mL}^{-1}$, ranging from $<0.27$ to 83.67 cells $\mathrm{mL}^{-1}$ across the sampling sites. The highest cell abundance was found at station $\mathrm{I} 3$ at a depth of $50 \mathrm{~m}$. At each station, the lowest cell abundances were found at 25 and/or $150 \mathrm{~m}$, whereas the depth with the highest abundances was at 50 and/or $75 \mathrm{~m}$, in close proximity to the DCM. A total of 17 coccolithophore taxa were counted (Table 2) across the study sites.

The nMDS ordination (Fig. 4) shows that at a level of $40 \%$ (dis)similarity in the HCA (see Supplement), three groups of water samples occurred: Group 1 mainly contained E. huxleyi and Umbellosphaera irregularis, with the lowest average cell concentrations of all the groups identified (8.57 cells $\mathrm{mL}^{-1}$ ), and represented the shallowest samples ( 25 and $50 \mathrm{~m}$ ). Most of the samples were located at $25 \mathrm{~m}$ and some at $50 \mathrm{~m}$, (Fig. 5) and were representative of oligotrophic conditions in the upper mixed layer. Group 2 was dominated by E. huxleyi, with the highest average cell concentration $\left(27.38\right.$ cells $\left.\mathrm{mL}^{-1}\right)$ of all the groups. Samples in this group were usually located at depths between 45 and 


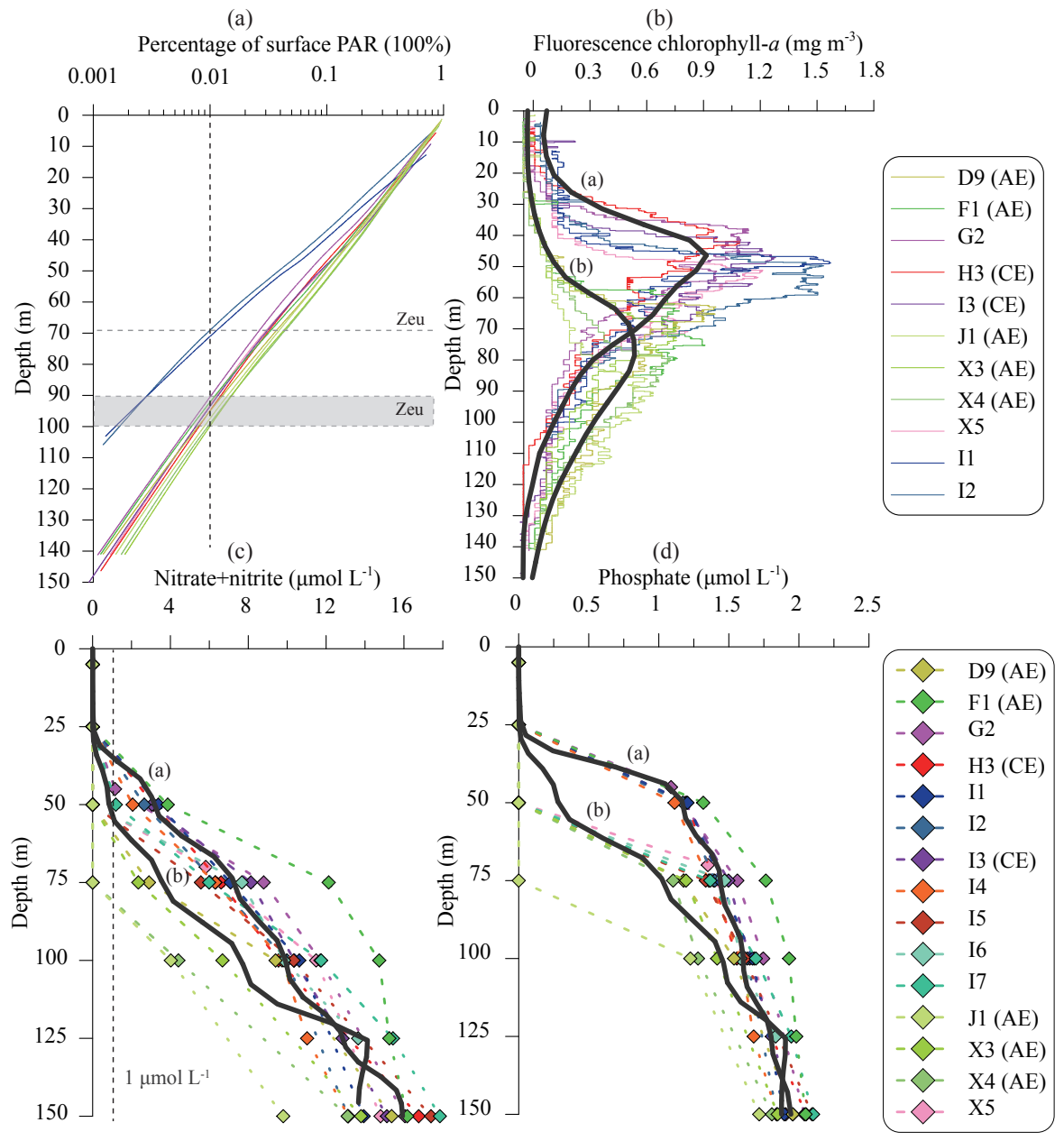

Figure 3. Vertical profiles of (a) percentage of surface photosynthetically active radiation (PAR), (b) fluorescence chlorophyll $a$ (mg $\mathrm{m}^{-3}$ ), (c) nitrate + nitrite, and $(\mathbf{d})$ phosphate concentration $\left(\mu \mathrm{mol} \mathrm{L}{ }^{-1}\right)$. Euphotic zone depth $($ Zeu $)$ is defined as $1 \%$ of surface irradiance penetration. The black lines denote moving average of 30 grid points of cyclonic eddy (CE, a) and anticyclonic eddy (AE, b) stations.

$75 \mathrm{~m}$ (Fig. 5), around $25 \mathrm{~m}$ below the MLD and representing the DCM, with elevated nutrients. Group 3 included taxa representing the lower photic zone (A. robusta, F. profunda), with $E$. huxleyi also abundant in most samples. Samples in Group 3 were found at 75 and $100 \mathrm{~m}$ depth (Fig. 5), in which mean cell concentrations were 17.43 and 9.04 cells $\mathrm{mL}^{-1}$, respectively.

\subsection{Estimates of coccolith and coccosphere calcite}

The mean concentration of detached coccoliths was 158 coccoliths $\mathrm{mL}^{-1}$, with a range of 0 to 673 coccoliths $\mathrm{mL}^{-1}$. The highest detached coccolith concentration was observed at station $\mathrm{F} 1$ at $75 \mathrm{~m}$, corresponding to the highest cell number $\left(22.87\right.$ cells $\left.\mathrm{mL}^{-1}\right)$ at this station. However, this pattern was not common at some stations. For example, the second-highest detached coccolith concentration (623 coccoliths $\mathrm{mL}^{-1}$ ) was found at station D9 at $150 \mathrm{~m}$, the easternmost station sampled (Fig. 1), where coccosphere concentra- tion was low $\left(1.87\right.$ cells $\left.\mathrm{mL}^{-1}\right)$. It is unlikely that such high abundances of detached coccoliths in deep layers of the water column could be produced in situ when cell abundances are so low, and hence these features may indicate either lateral or vertical transport.

Based on coccosphere and detached coccolith concentrations, estimated total calcite concentrations ranged from $\sim 0$ to $5258.1 \mathrm{pg} \mathrm{C} \mathrm{mL}^{-1}$, with a cruise average of $1508.3 \mathrm{pg} \mathrm{C} \mathrm{mL}^{-1}$. Estimated total calcite concentrations roughly mirrored detached coccolith concentrations (Fig. 6; Spearman's rank correlation, $r_{\mathrm{s}}=0.81, p<0.01, n=67$ ), highlighting the contribution of detached coccoliths to particulate calcite in the water column. Our estimated calcite concentrations were in the same range as those estimated by Beaufort et al. (2008) in the southeast Pacific (2224 $\mathrm{pg} \mathrm{C} \mathrm{mL}^{-1}$ on average). The cruise average calcite concentrations based on three important coccolithophore species (E. huxleyi, Gephyrocapsa oceanica, and F. pro- 
Table 2. Coccolithophore species composition in Group 1, Group 2, and Group 3. $R$ : mean relative abundance; $F$ : occurrence frequency. Bold numbers indicate the representative species in their groups.

\begin{tabular}{lrr|rr|r|rr}
\hline & \multicolumn{2}{c|}{ Group 1 } & \multicolumn{2}{c|}{ Group 2 } & \multicolumn{2}{c}{ Group 3 } \\
\cline { 2 - 7 } & $R$ & $F$ & $R$ & $F$ & $R$ & $F$ \\
\hline Algirosphaera robusta & 0.39 & 23.53 & 2.22 & 66.67 & $\mathbf{1 9 . 7 8}$ & $\mathbf{9 2 . 8 6}$ \\
Florisphaera profunda & 0.35 & 17.65 & 1.34 & 41.67 & $\mathbf{4 3 . 8 1}$ & $\mathbf{1 0 0 . 0 0}$ \\
Gladiolithus flabellatus & 0.00 & 0.00 & 0.00 & 0.00 & $\mathbf{1 . 6 6}$ & $\mathbf{6 0 . 7 1}$ \\
Emiliania huxleyi & $\mathbf{3 6 . 9 7}$ & $\mathbf{9 4 . 1 2}$ & $\mathbf{6 6 . 8 4}$ & $\mathbf{1 0 0 . 0 0}$ & $\mathbf{2 2 . 6 5}$ & $\mathbf{9 2 . 8 6}$ \\
Gephyrocapsa oceanica & 2.29 & 41.18 & $\mathbf{1 0 . 2 3}$ & $\mathbf{9 1 . 6 7}$ & 1.65 & 46.43 \\
Gephyrocapsa ericsonii & 6.20 & 52.94 & 6.20 & 50.00 & 2.61 & 32.14 \\
Umbellosphaera irregularis & $\mathbf{3 4 . 3 5}$ & $\mathbf{9 4 . 1 2}$ & 0.86 & 41.67 & 0.24 & 7.14 \\
Umbellosphaera tenuis & 2.14 & 47.06 & 0.10 & 16.67 & 0.00 & 0.00 \\
Discosphaera tubifera & $\mathbf{4 . 4 1}$ & $\mathbf{8 2 . 3 5}$ & 0.11 & 8.33 & 0.00 & 0.00 \\
Rhabdosphaera clavigera & 0.82 & 23.53 & 0.04 & 8.33 & 0.00 & 0.00 \\
Calcidiscus leptoporus & 0.82 & 17.65 & 1.53 & 58.33 & 0.96 & 35.71 \\
Oolithotus fragilis & 3.64 & 35.29 & 6.95 & 83.33 & 3.87 & 78.57 \\
Helicosphaera carteri & 1.05 & 58.82 & 0.21 & 25.00 & 0.03 & 3.57 \\
Syracosphaera spp. & 3.92 & 94.12 & 1.56 & 83.33 & 1.55 & 53.57 \\
Umbilicosphaera sibogae & 0.45 & 17.65 & 0.71 & 33.33 & 0.22 & 14.29 \\
Calciosolenia spp. & 0.49 & 23.53 & 0.48 & 58.33 & 0.41 & 21.43 \\
Michaelsarsia spp. & 1.71 & 35.29 & 0.61 & 41.67 & 0.54 & 25.00 \\
\hline
\end{tabular}

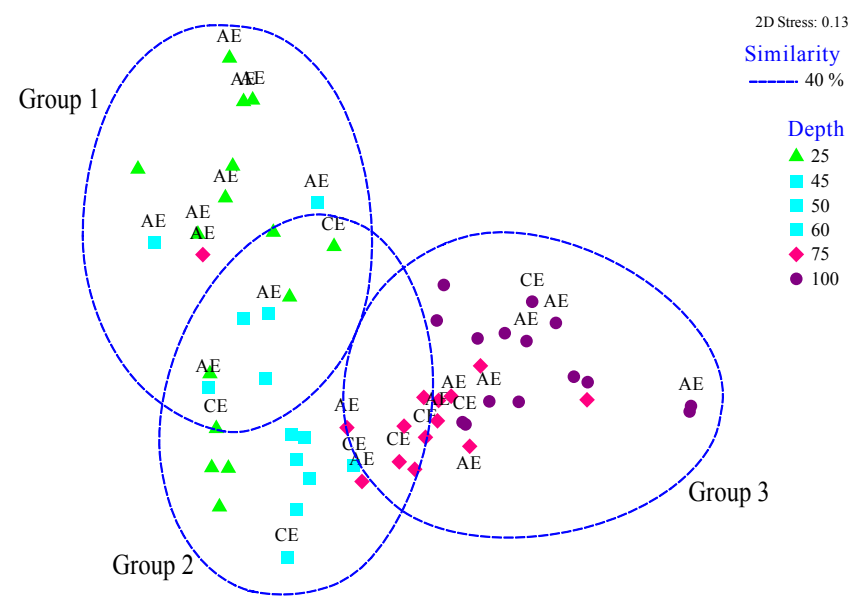

Figure 4. Nonmetric multidimensional scaling (nMDS) ordination of stations at different depths, based on Bray-Curtis similarity. The 0.13 stress of two-dimensional ordination can provide a good interpretation for community groups (Clarke and Warwick, 2001). The blue dashed lines indicate different divisions at $40 \%$ (dis)similarity; the divisions are determined by cluster analysis, using the same resemblance as nMDS. CE: cyclonic eddy; AE: anticyclonic eddy.

funda) which dominate surface sediments (Cheng and Wang, 1997; Fernando et al., 2007) and deep-sea coccolith fluxes (Jin et al., unpublished) in the SCS were 273.0, 112.1, and $391.3 \mathrm{pg} \mathrm{C} \mathrm{mL}^{-1}$, respectively. Their average relative contributions to water-column calcite were also estimated: $E$. huxleyi $(17.04 \%)$, G. oceanica $(7.00 \%)$, and F. profunda $(24.42 \%)$ contributed to around half of water-column cal- cite concentrations (Fig. 7). The depth distribution of these species contributions to total calcite matched well with their average depth distribution across the study area: E. huxleyi and $G$. oceanica contributions were highest in the upper water column ( 25 and $50 \mathrm{~m}$ ), and $F$. profunda contributions were highest at depths of 75 and $100 \mathrm{~m}$.

\subsection{Emiliania huxleyi biometry}

From all the samples analyzed, the average DSL of E. huxleyi type A was $2.96 \mu \mathrm{m}$, with an overall standard deviation of $0.39 \mu \mathrm{m}$. Pearson's product-moment correlations showed the relationships between average DSL, nutrients (nitrite + nitrate, phosphate), carbonate chemistry $\left(\mathrm{pH}, \Omega_{\mathrm{C}}\right.$ and $A_{\mathrm{T}}$ ), and temperature $(T)(n=29$, Table 3$)$. Statistically significant $(p<0.01)$ correlations were found between DSL, total nitrogen (nitrite + nitrate), and phosphate (positive) and between $\mathrm{pH}$ and $\Omega_{\mathrm{C}}$ (negative), whereas no correlation occurred between DSL, $A_{\mathrm{T}}$, and $T$. The mean coccosphere diameter of E. huxleyi across all those measured was $6.41 \mu \mathrm{m}$, with a standard deviation of $0.95 \mu \mathrm{m}$. The average number of coccoliths estimated per coccosphere was 32 , with an overall range of 16 to 48 . CD showed a statistically significant positive relationship with DSL (Pearson's $r=0.71, p<0.01$, $n=102)$ and coccolith number per sphere $(N)$ (Pearson's $r=0.87, p<0.01, n=102)$, and the correlation was also significant between DSL and N (Pearson's $r=0.51, p<0.01$, $n=102$ ). A linear regression gave a coccosphere diameter of $\mathrm{CD}=0.205 \times \mathrm{DSL}+1.664\left(R^{2}=0.49, p<0.01\right)$, and a binary regression equation also gave a coccosphere diame- 

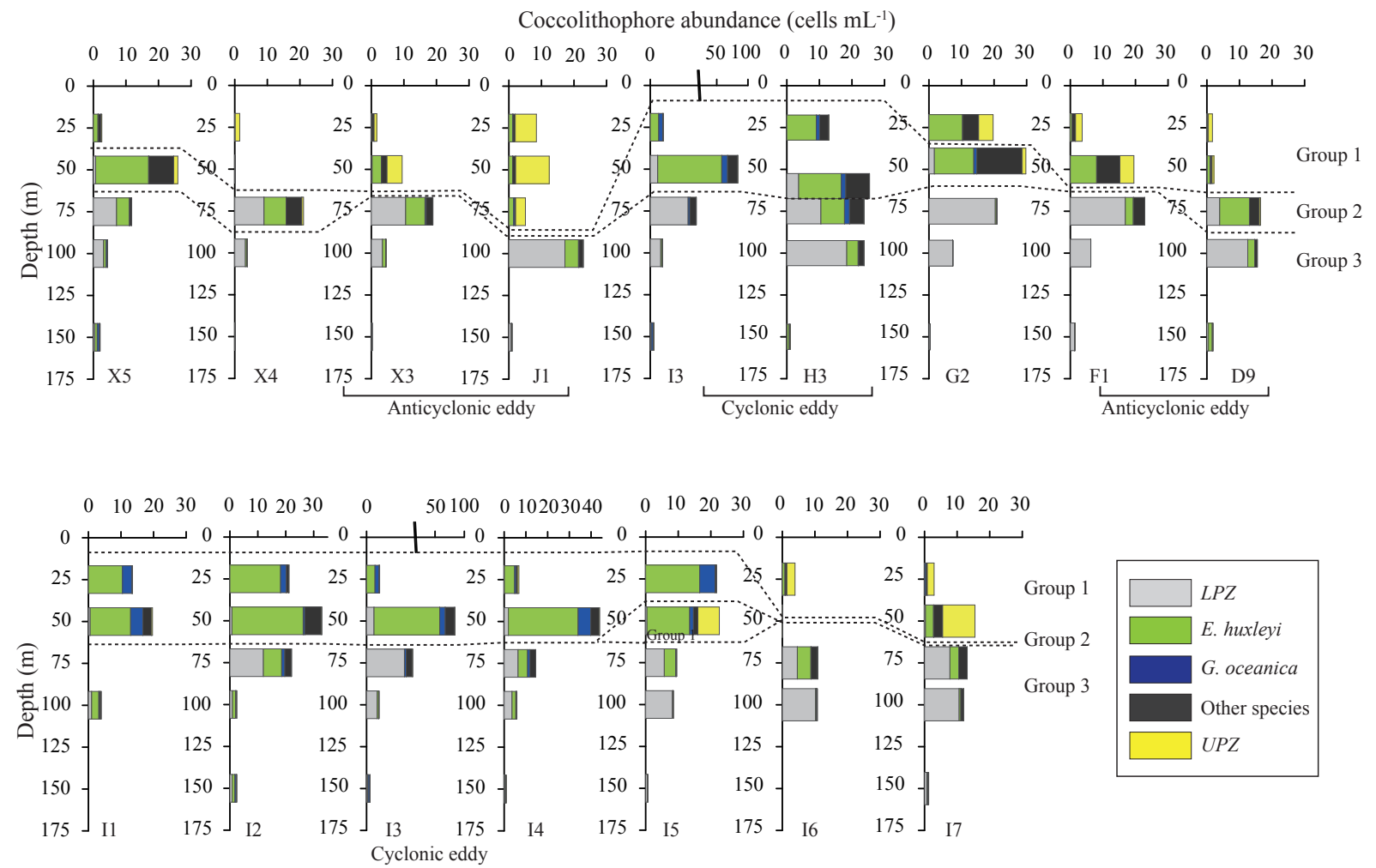

Figure 5. Coccolithophore abundance (cells $\mathrm{mL}^{-1}$ ) of three groups at sampling stations. "LPZ" specifically indicates three species: $F$. profunda, A. robusta, and G. flabellatus. "UPZ" specifically indicates Umbellosphaera spp., D. tubifera, and R. clavigera.

ter of $\mathrm{CD}=1.205 \times \mathrm{DSL}+0.106 \times N+0.096\left(R^{2}=0.85\right.$, $p<0.01$ ).

\section{Discussion}

\subsection{Coccolithophore biogeography in the South China Sea}

In the context of the coccolithophore biogeographical zones of Winter et al. (1994), the coccolithophore assemblages investigated in the SCS belong to the tropical zone, comprising E. huxleyi, G. oceanica, Gephyrocapsa ericsonii, Oolithotus fragilis, $U$. irregularis, $F$. profunda, and A. robusta. Reticulofenestra sessilis was also sporadically found at $75 \mathrm{~m}$ depth at sampling stations, and this species is reported to be exclusively found in lower photic water of the tropical zone, where it may form symbioses with diatoms (i.e., Thalassiosira species) (Winter et al., 1994; Young et al., 2003; Jordan, 2012). The coccolithophore flora of the SCS is similar to the "high temperature" and "warm oligotrophic" assemblages in the equatorial Pacific Ocean (Hagino et al., 2000).

The two dominant species in our samples from the SCS were E. huxleyi and F. profunda, species representative of the upper and lower photic zone floral groups (Winter et al. 1994). These floral groups both live within the euphotic zone
(>1\% surface irradiance), which is about $100 \mathrm{~m}$ in summer in the SCS. However, in the western Pacific warm pool (stratified waters) and subtropical gyres of the Pacific and Atlantic oceans, species $F$. profunda are found much deeper (150 to $250 \mathrm{~m}$ ) in the water column (Hagino et al., 2000; Boeckel and Baumann, 2008; Beaufort et al., 2008). These differences are undoubtedly linked to differences between the SCS and open ocean in terms of the depths of the thermocline and nutricline, implying that the SCS is relatively eutrophic when compared with tropical and subtropical settings at a similar latitude.

\subsubsection{Upper photic zone (UPZ) assemblage}

In our nMDS analysis, the UPZ assemblage (Winter et al., 1994) was represented by Groups 1 and 2, found at 25 and $50 \mathrm{~m}$ in the SCS. These two groups have different species composition in our analysis; for example, Group 1 included umbelliform species, i.e., $U$. irregularis, which are considered $K$ selected (specialist) species (Young, 1994), and this agrees with previous work (e.g., Okada and Honjo, 1975). The UPZ assemblage is commonly observed in wellstratified, oligotrophic, warm surface waters in the western Pacific warm pool (Hagino et al., 2000). In the SCS, U. irregularis was mostly found at stations with deep mixed layers, deep nutriclines, and extremely low nutrients in sur- 

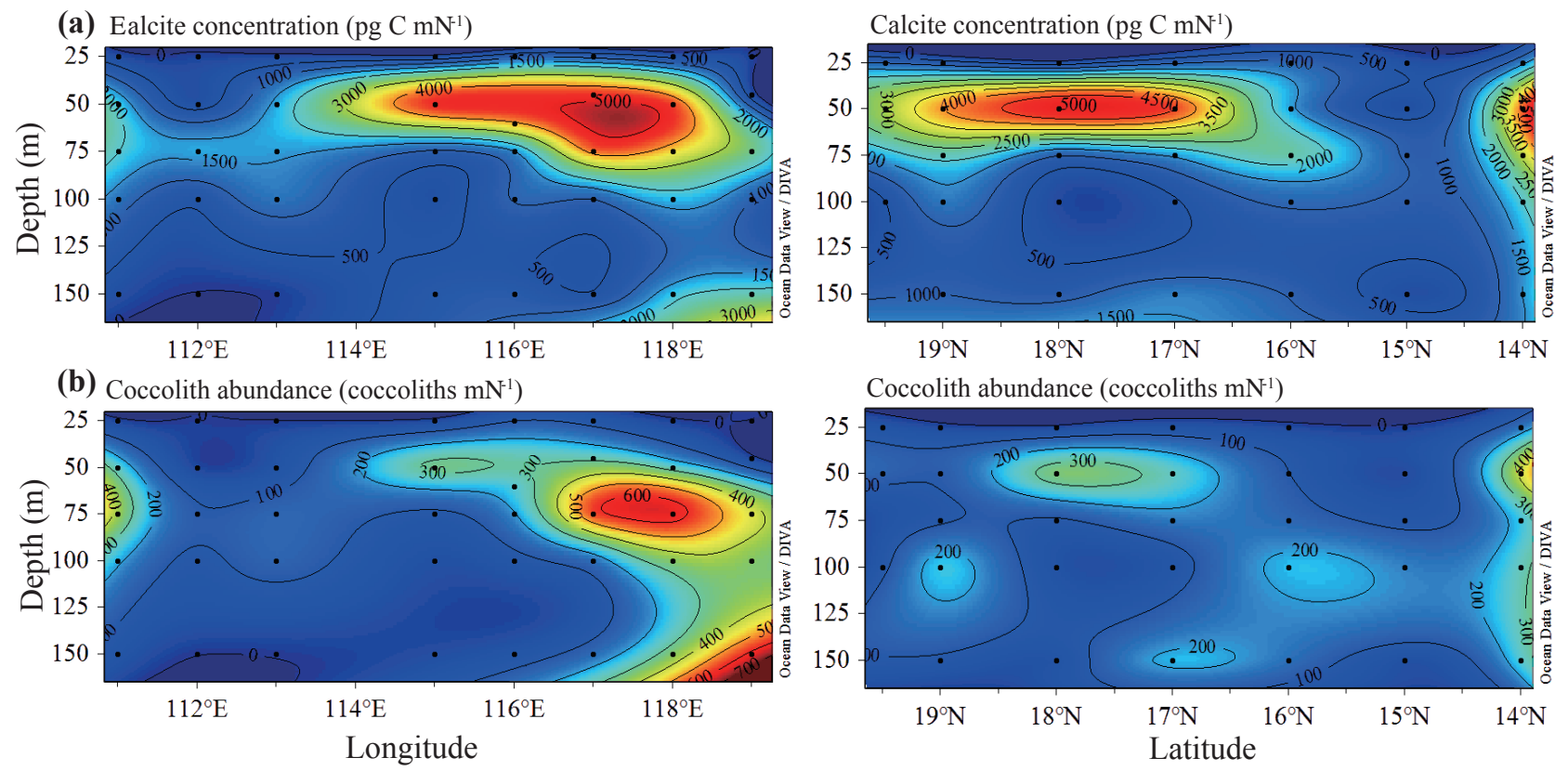

Figure 6. Coccolithophore-based calcite concentration (a) and detached coccolith concentration (b) in zonal and meridional sections.

face waters. In comparison, Group 2 occurred at stations with shallower mixed layers and nutriclines and hence potentially elevated nutrient supplies, and coccolithophores in this group were most abundant and diverse, which indicates that this community was slightly productive when compared with those in other groups. The E. huxleyi dominance contradicts other studies in the SCS in summer, such as Okada and Honjo (1975) and Sun et al. (2011), who found that $G$. oceanica was the dominant species (30 to $100 \%$ of total cell numbers) in the western and southern parts of the SCS. Differences between this study and others could relate to the influence of the Asian summer monsoon on the western and southern SCS, where the southwesterly wind causes a winddriven upwelling system off the east coast of Vietnam (Liu et al., 2002; Xie et al., 2003; Ning et al., 2004). G. oceanica is considered a more eutrophic and coastal species (Andruleit and Rogalla, 2002; Andruleit et al., 2003), and hence it contributed less to coccolithophore cells in the central and northern part of SCS, where summer-monsoon-induced upwelling or water mixing is weak.

Morphotype A was the dominant morphotype of $E$. huxleyi in the SCS. Different morphotypes of E. huxleyi can be distinguished by coccolith characteristics such as DSL, element widths, and features of the central area (e.g., Young et al., 2003; Hagino et al., 2011) and may be considered different ecotypes with different temperature and nutrient preferences (Cook et al., 2011; Poulton et al., 2011; Hagino et al., 2011; Saavedra-Pellitero et al., 2014). In general, E. huxleyi type $\mathrm{A}$ shows a warmer-water preference than type $\mathrm{B}$ and other type $\mathrm{B}$ derivatives $(\mathrm{C}, \mathrm{B} / \mathrm{C})$. In our observations, type $\mathrm{C}$ E. huxleyi coccospheres or coccoliths were only found
Table 3. Pearson's product-moment correlations $(r)$ between mean distal shield length (DSL) of E. huxleyi, principal component 1 $(\mathrm{PC}-1)$ scores and environmental parameters: nitrate + nitrite $(\mathrm{N})$, phosphate $(\mathrm{P}), \mathrm{pH}$, total alkalinity $\left(A_{\mathrm{T}}\right), \mathrm{CaCO}_{3}$ saturation $\left(\Omega_{\mathrm{C}}\right)$, and temperature $(T)(n=29)$. The principal component analysis is based on all the environmental parameters, with a PC- 1 contribution of $76.59 \%$ to total variance. ${ }^{*} p<0.05$; ${ }^{* *} p<0.01$.

\begin{tabular}{lll}
\hline & Mean DSL & PC-1 $(76.59 \%)$ \\
\hline $\mathrm{N}$ & $0.601^{* *}$ & $-0.967^{* *}$ \\
$\mathrm{P}$ & $0.579^{* *}$ & $-0.965^{* *}$ \\
$\mathrm{pH}$ & $-0.526^{* *}$ & $0.804^{* *}$ \\
$A_{\mathrm{T}}$ & 0.274 & $-0.671^{* *}$ \\
$\Omega_{\mathrm{C}}$ & $-0.395^{*}$ & $0.958^{* *}$ \\
$T$ & -0.21 & $0.842^{* *}$ \\
\hline
\end{tabular}

sporadically in SEM images, and the predominant occurrences of morphotype A could be related to the prevailing high sea-surface temperature $\left(>26^{\circ} \mathrm{C}\right)$ in the study area. The southern part of SCS is also within the western Pacific warm pool, where sea-surface temperature is consistently $>28^{\circ} \mathrm{C}$ all year round (Yan et al., 1992).

\subsubsection{Lower photic zone (LPZ) assemblage}

In the present study, the LPZ was represented by Group 3, which included typical LPZ species (F. profunda, A. robusta, and G. flabellatus) and was found between 75 and $100 \mathrm{~m}$. Group 3 occurred above, at, or near the depth where $1 \%$ of surface irradiance penetrated (i.e., base of the euphotic 

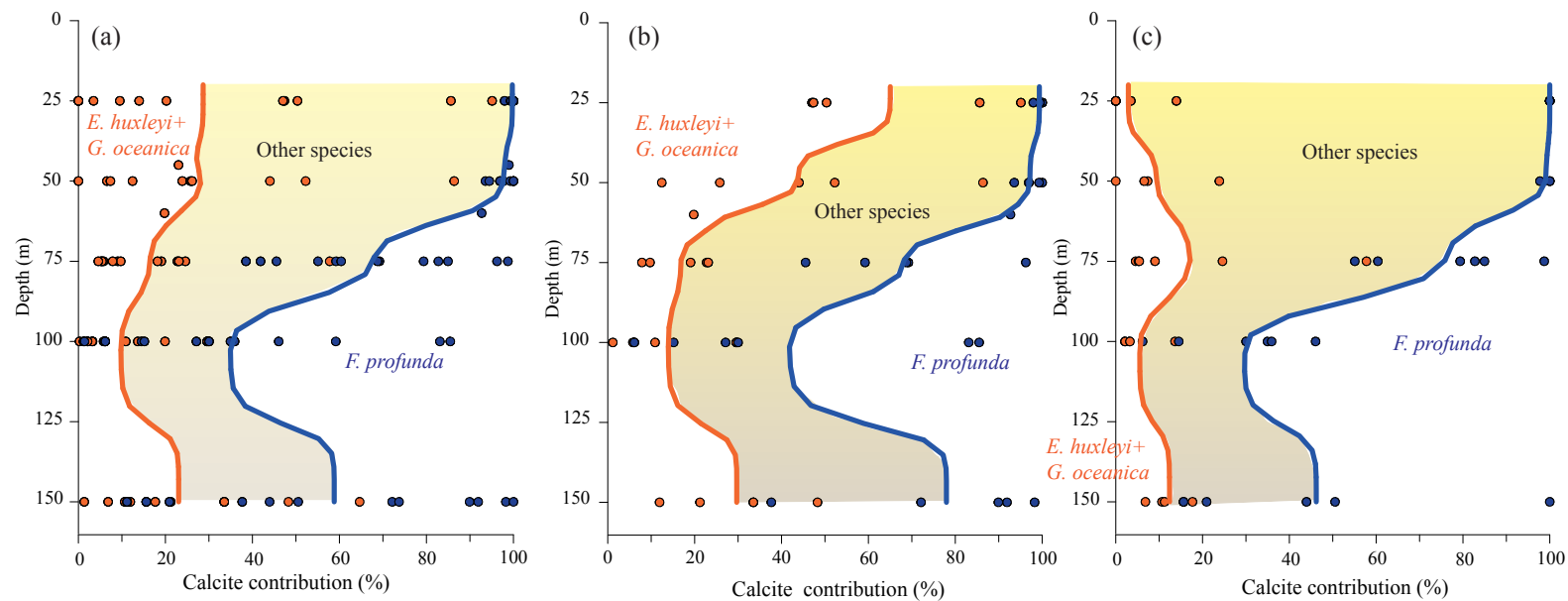

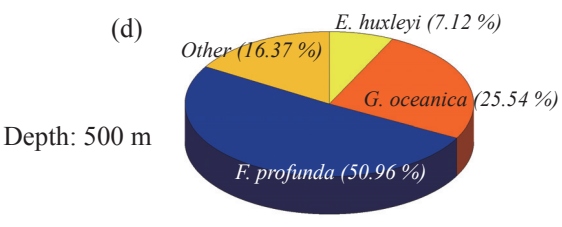

Calcite contribution (\%)

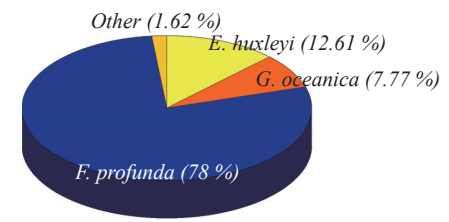

Coccolith relative abundance $(\%)$

Figure 7. The relative contribution of E. huxleyi + G. oceanica and F. profunda to coccolithophore-based calcite concentration in the water column at all stations (a); at I1, I2, I3, I4, I5, and H3 (b); and at X3, X4, I6, I7, F1, and D9 (c). The solid lines denote moving average of 30 grid points. (d) Yearly averaged coccolith relative abundance and their contribution to coccolith-based calcite in sediment trap $\left(117.46^{\circ} \mathrm{E}\right.$ $20^{\circ} \mathrm{N}, 500 \mathrm{~m}$ ) in the South China Sea (Jin et al., unpublished).

zone). In other tropical oceans, the LPZ assemblage dwells deeper than the base of the euphotic zone (Hagino et al., 2000; Boeckel and Baumann, 2008; Beaufort et al., 2008). In the northern Arabian Sea, F. profunda inhabits shallower waters and is found across a wider depth range (10 to $80 \mathrm{~m}$ ) (Andruleit et al., 2003). It is worth noting that, as in the SCS, the Arabian Sea is strongly controlled by a monsoonal system (Indian monsoon) and is considered relatively eutrophic (Andruleit and Rogalla, 2002; Andruleit et al., 2003). Hence, it can be inferred that neither water depth nor light availability is a limiting factor for $F$. profunda (and/or other LPZ species) in the SCS, but rather nutrient availability is important; the nutricline is relatively shallow (50 to $75 \mathrm{~m}$ ) even in the oligotrophic summer in the SCS.

\subsection{The response of coccolithophores to eddies in the South China Sea}

Mesoscale eddies have a strong influence on productivity and ecosystem structure in the SCS (Chen et al., 2007b; Lin et al., 2010; Wang et al., 2016). Previous measurements in the SCS have shown that integrated primary production in cyclonic eddies can be 2-3-fold higher relative to the outside of eddies (Chen et al., 2007b). Modeling results have also highlighted how new production can be $\sim 30 \%$ higher or lower, relative to outside of eddies, in cyclonic or anticyclonic eddies, respectively (Xiu and Chai, 2011).

Results from nMDS, HCA, and eddy settings in the $18^{\circ} \mathrm{N}$ section clearly show that the coccolithophore communities in the SCS were strongly coupled with eddy occurrences (Fig. 5). In the cyclonic eddy (I3, H3), Group 2 occurred in ranges of 25 to $50 \mathrm{~m}$ depth and Group 3 occurred within layers from 75 to $100 \mathrm{~m}$. Comparatively, at stations (X5, G2) with "normal" (non-eddy) conditions, three groups sequentially occurred in the water column: Group 1 at $25 \mathrm{~m}$, Group 2 at $50 \mathrm{~m}$, and Group 3 between 75 and $100 \mathrm{~m}$ depth. In anticyclonic eddies, there were two patterns: one with Group 1 distributed within a wider depth range (from 25 to $50 \mathrm{~m}$ ) and Group 3 only within a 100 m layer; the other was that Group 2 was absent, and the maximum coccolithophore abundance depth was deep and belonged to Group 3, which was dominated by LPZ assemblages (e.g., F. profunda). This variation highlights the importance of the ecological effects of eddies on the coccolithophore community's depth distribution through the water column. As the anticyclonic eddy (cyclonic eddy) centers lead to convergence (divergence) of the adjacent waters, they deepen (shoaling) the nutricline and creating more oligotrophic (slightly eutrophic) conditions in the water column which favor distinct coccolithophore assemblages (Fig. 8). 

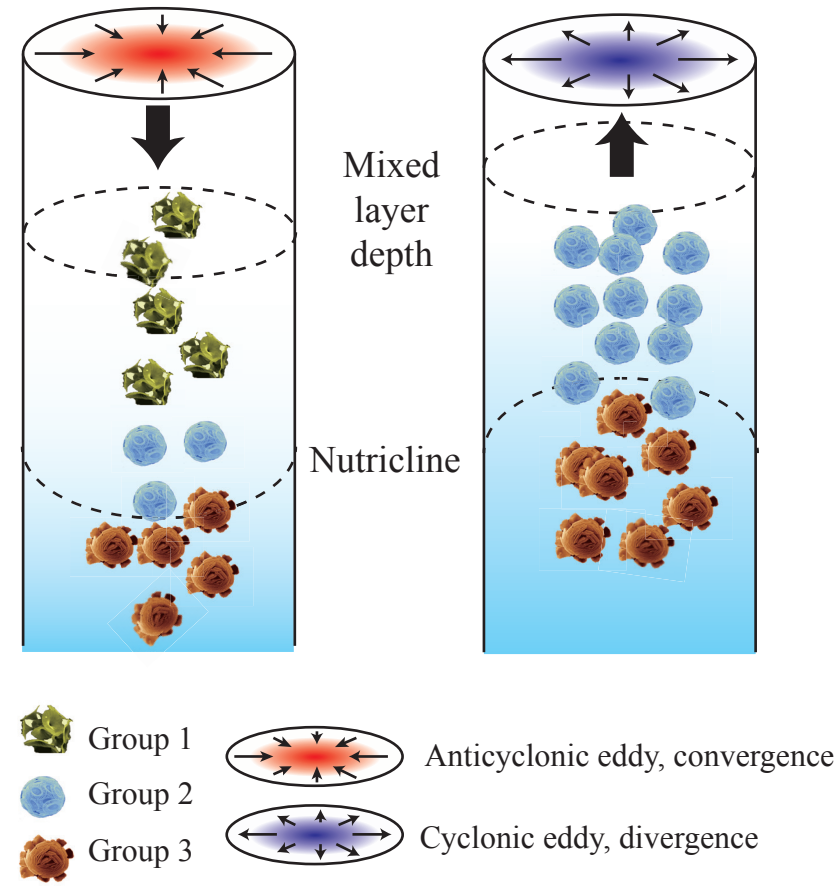

Figure 8. Schematic showing the coccolithophore communities in an anticyclonic eddy and a cyclonic eddy.

Due the discontinuous sampling dates (Table 1) and low resolution of environmental data at some stations, the meridional section may not be suitable for assessing the eddy impacts on coccolithophore communities. For example, at I6 and I7, stations were not characteristic of anticyclonic eddies based on the SLA and geostrophic flow map; however, the coccolithophore community vertical composition or structure is similar to those in the anticyclonic eddies. This may be due to the deeper nutricline in the central basin of the SCS, even if the water-column structure had not been modulated by eddies in our investigation. Another example is stations I1 and I2, for which the coccolithophore groups agreed with those in the cyclonic eddies. Likewise, this was also not characteristic of the cyclonic eddies, as shown by SLA and geostrophic flow (Supplement). At stations I1 and I2, the euphotic zone depth was relatively shallow $(\sim 70 \mathrm{~m})$, with more light attenuation from suspended particles, which could be caused by elevated particle production. This finding corresponds to the station locations at the edge of the anticyclonic eddy where particulate organic carbon (POC) fluxes can be 2-4-fold higher than those in adjacent oligotrophic waters (Zhou et al., 2013; Shih et al., 2015). For station I4, the case was similar to I1 and I2, as it was located at the edge of two large anticyclonic eddies (supplement). The horizontal advection, for water mass balance, can result in the elevated nutricline in anticyclonic eddy edges and, hence, the enhancement of POC production and export (Zhou et al., 2013).
Station I5 had another distinctive arrangement of species assemblages, which was the opposite of that found at the other stations sampled (Fig. 5); Group 2 was found at $25 \mathrm{~m}$ while Group 1 was at $50 \mathrm{~m}$. Examination of the temperature profile shows that the $29.5^{\circ} \mathrm{C}$ isotherm was shallow and domed, while the $22.5^{\circ} \mathrm{C}$ isotherm was pushed deeper into the water column (Fig. 2b). Filters collected at 25 and $50 \mathrm{~m}$ from $\mathrm{I} 5$ also had lots of diatom fragments and relatively elevated coccolithophore abundances (21.75 and 22.59 cells $\mathrm{mL}^{-1}$ at 25 and $50 \mathrm{~m}$, respectively). We suggest that this feature may represent a mode-water eddy, as described by McGillicuddy et al. (2007) in the northeast subtropical Atlantic Ocean. McGillicuddy et al. (2007) observed elevated phytoplankton production (i.e., a diatom bloom) in a mode-water eddy, which led to local changes in the zooplankton community composition (McGillicuddy et al., 2007; Eden et al., 2009).

\subsection{Calcite concentrations in the South China Sea}

The discrete estimates of bulk coccolith calcite roughly covaried with coccolith and coccolithophore concentration in the water column, with peak concentrations around the DCM. Excluding the maximum calcite concentration in the DCM, another peak was also found in deeper water at some stations, for example at $150 \mathrm{~m}$ in F1 and D9 and 100 and $150 \mathrm{~m}$ in I7, where the cell concentrations were low and calcite was nearly entirely contributed by detached coccoliths. In addition, the relative calcite contribution of different taxa changed in different trophic levels of the water column. For example, the relative calcite contribution of the common placolith (i.e., G. oceanica and E. huxleyi) was higher in the water column with slightly euphotic stations (e.g., stations with cyclonic eddy, shallow DCM, and nutricline; Fig. 3). Their contribution decreased and the contribution of F. profunda increased with the deepening of water depth, whereas the contribution of other species remained constant (Fig. 7b). In contrast, these placoliths contributed less in water columns with an oligotrophic station (e.g., stations with anticyclonic eddy, deep DCM, and nutricline; Fig. 3), and an elevated contribution of other species was found in the upper $\sim 50 \mathrm{~m}$ of the water column (Fig. 7c). E. huxleyi, G. oceanica, and $F$. profunda represented around half of the calcite in the water column, whereas other species with smaller levels of abundance contribute to the other $50 \%$ of water-column calcite. The greater contribution of these relatively less abundant species in calcite inventories is partly related to higher per coccolith calcite contents, due in part to larger coccolith lengths (Young and Ziveri, 2000); for example, O. fragilis has $>80 \mathrm{pg} \mathrm{C}$ per coccolith, whereas $E$. huxleyi has $\sim 2 \mathrm{pg}$ $\mathrm{C}$ per coccolith. Relatively rare coccolithophore species with high coccolith and coccosphere calcite contents are important vectors of both upper-ocean calcite production (Daniels et al., 2014) and deep-sea calcite fluxes (Ziveri et al., 2007). However, an examination of sediment trap material $(500 \mathrm{~m}$ 

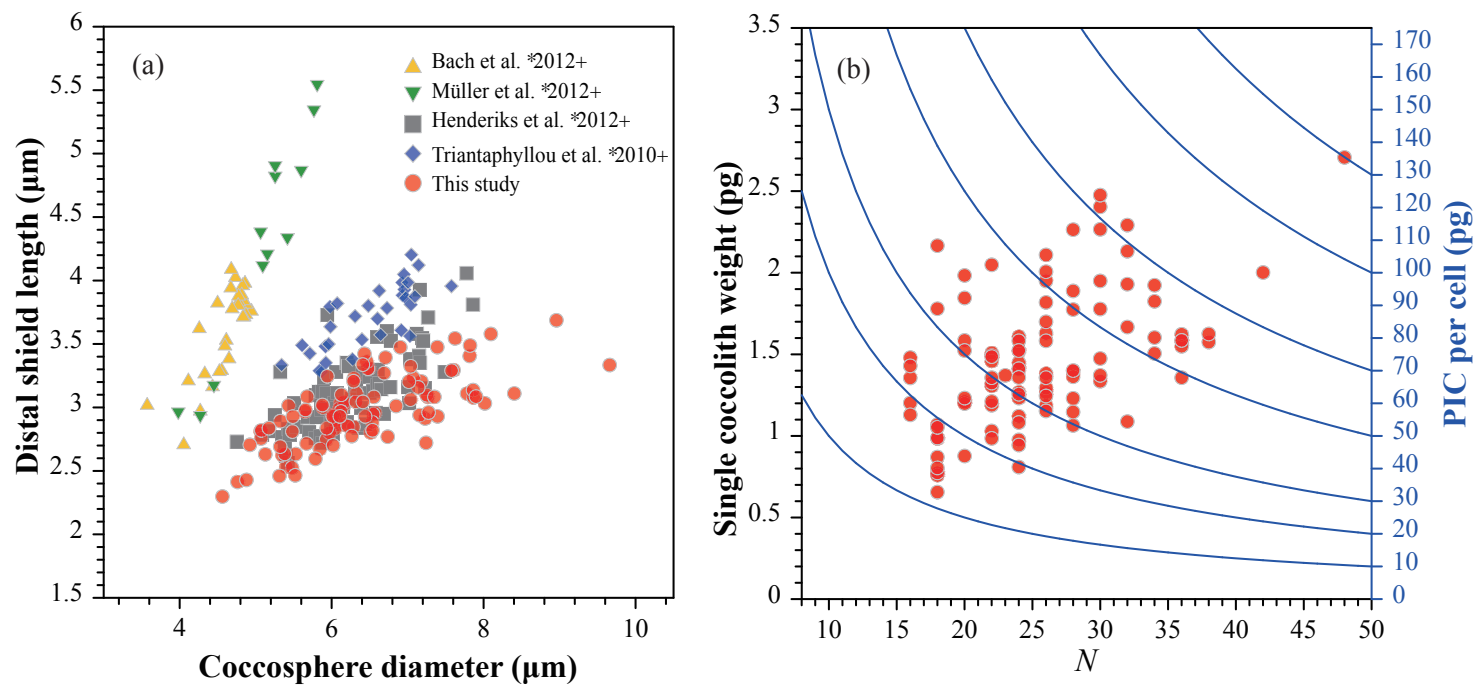

Figure 9. E. huxleyi distal shield length plot versus coccosphere diameter (a) in the present study with comparison with those from other field and culturing samples (Triantaphyllou et al., 2010; Henderiks et al., 2012; Bach et al., 2012; Müller et al., 2012). These E. huxleyi biometry data are derived from Fig. 6 in Müller et al. (2012). (b) Scatterplot of single coccolith weight (calculated from Eq. 2) and number of coccoliths per coccosphere $(N)$, showing the particulate inorganic carbon (PIC) per cell.

depth, $1500 \mathrm{~m}$ above the sea floor) in the northern SCS basin shows that these three species (E. huxleyi, G. oceanica, and $F$. profunda) dominating upper-ocean calcite inventories all have an increased contribution to coccolith (>95\%) and coccolith calcite (> $80 \%$ ) fluxes (Fig. 7d, Jin et al., unpublished). The significant loss of the calcite contribution from other species highlights the discrepancy between coccolith calcite in the euphotic upper water column and aphotic deep ocean. Notably, at $150 \mathrm{~m}$ for some stations (D9, F1, G2, I5, X3), these three species can comprise more than 70 to $90 \%$ of calcite inventories and the contribution of $G$. oceanica exceeds that of E. huxleyi, which is similar to the fluxes of sediments of moored traps. One possible reason is that these coccoliths are attributed to lateral transport of the nepheloid layer originating from the continental shelf or slope. This is the most likely case for D9 and F1, as they have such high detached coccolith concentrations (Fig. 6) and are located in the easternmost part of the $18^{\circ} \mathrm{N}$ section. Alternatively, coccoliths in the deep layer are a result of vertical sinking. They can indicate that the higher contribution of these species in the deep layer may result from their higher production rate in the photic zone, which cannot be reflected by the snapshot-like discrete sampling done in our study.

\subsection{Environmental influences on Emiliania huxleyi biometry}

Some parameters can describe coccolithophore calcification in field or culturing studies. Firstly, coccolith biometry, which includes the parameters of coccolith morphology such as shield length, thickness, and relative tube width (e.g., Poulton et al., 2011; Young and Ziveri, 2000; Young et al.,
2014), is directly associated with single-coccolith weight or calcite content. Our data indicate that the biometry parameters of the E. huxleyi coccosphere, i.e., CD, DSL, and N, are significantly correlated (results 3.4 ). The linear relationship between DSL and CD (morphotype A cells) was also reported in field (Triantaphyllou et al., 2010; Henderiks et al., 2012) and culture samples (Bach et al., 2012; Müller et al., 2012) (Fig. 9a). As suggested by Müller et al. (2012), it takes additional time for larger-sized cells to transport coccoliths from vesicle to cell surface and hence more time for coccolith maturation and formation so as to produce a largersized coccolith. By multiplying single-coccolith weight by the number of coccoliths per coccosphere, we get the cell calcite content, which mainly ranges from 10 to $70 \mathrm{pg}$ for an E. huxleyi type A cell in the SCS (Fig. 9b). The DSL/CD ratios for E. huxleyi type A in the culturing and field samples are both within their respective ranges, and the former is obviously higher than the latter (Fig. 9a), which can be attributed to the fact that changes in a sole environmental variant in sterile culture experiments can remarkably influence the physiology of coccolith formation, whereas the effects on coccolith formation can be muted due to the positive or negative responses to multiple environmental changes in the field (Müller et al., 2012). With the same DSL, coccosphere diameter in field samples is larger. It also seems that an E. huxleyi cell in the field can produce more or multilayer coccoliths, which could be a defense against zooplankton grazing or bacterial attack and offer mechanical protection (Young, 1994; Jaya et al., 2016) in natural conditions. As seen in Fig. 9b, the coccolith length is likely to be able to reflect the morphology of a whole coccosphere and its calcite content, i.e., the cel- 
(a) E. huxleyi $\left(\right.$ cells m/ $\left.{ }^{-1}\right)$ E. huxleyi $\left(\right.$ cells m/ $\left.{ }^{-1}\right)$ E. huxleyi $\left(\right.$ cells m/ $\left./^{-1}\right)$ E. huxleyi $\left(\right.$ cells m/ $\left./^{-1}\right)$ E. huxleyi $\left(\right.$ cells $\left.\mathrm{m}^{-1}\right)$

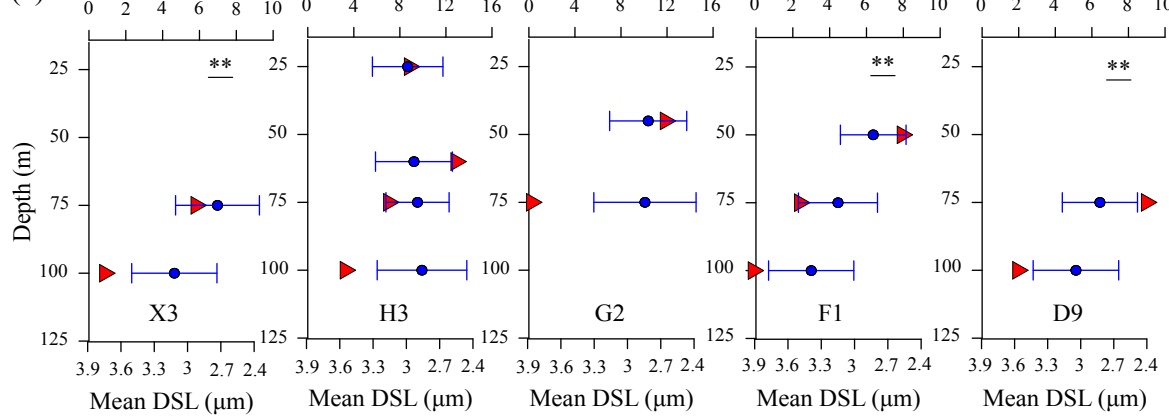

E. huxleyi $\left(\right.$ cells m/ $\left./^{-1}\right)$ E. huxleyi $\left(\right.$ cells m/ $\left.{ }^{-1}\right)$ E. huxleyi $\left(\right.$ cells $\left.\mathrm{m} /{ }^{-1}\right)$ E. huxleyi $\left(\right.$ cells $\left.\mathrm{m} /{ }^{-1}\right)$ E. huxleyi $\left(\right.$ cells $\left.\mathrm{m} /{ }^{-1}\right)$

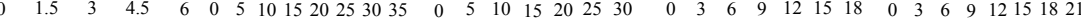
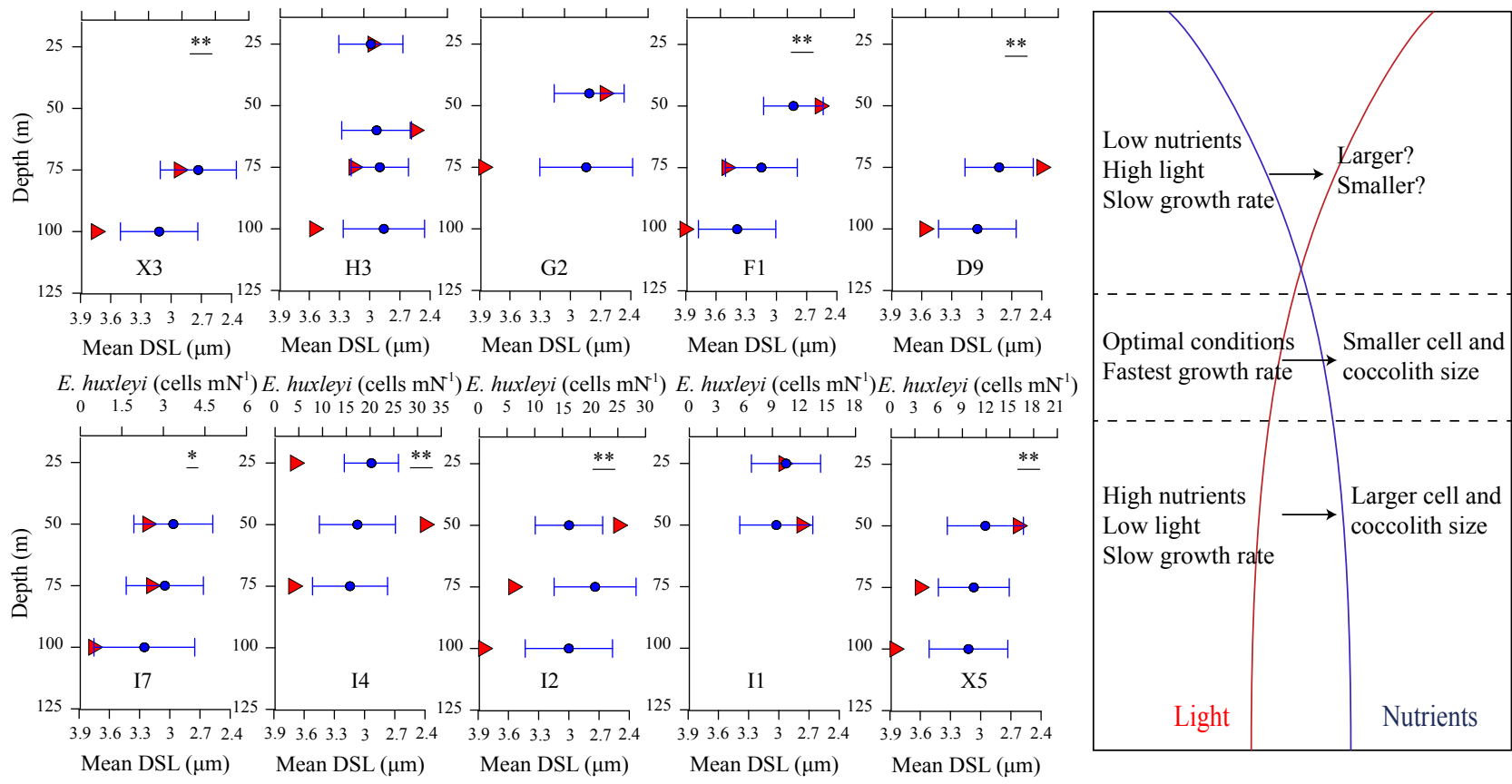

E. huxleyi $\left(\right.$ cells $\left.\mathrm{m} /{ }^{-1}\right)$

E. huxleyi mean DSL $(\mu \mathrm{m})$, error bar $=1$ standard deviation $\quad$ One-way ANOVA $\underset{* *}{*} \mathrm{p}<0.01, \underset{*}{*} \mathrm{p}<0.05$

Figure 10. (a) Cell abundance (red triangles) and mean distal shield length (DSL, blue dots; error bar: 1 SD) of E. huxleyi plotted at stations where there were at least two biometry measurement points. (b) A schematic map showing light and nutrient conditions in relation to coccolithophore growth rate and cell or coccolith size.

lular particulate inorganic carbon (PIC) content. And further, the linear relationship between the morphological parameters makes it possible to reconstruct coccolithophore cell volume in geological records (Henderiks, 2008).

The second parameter is PIC production rate, i.e., the calcification rate, which is calculated by the equation $P_{\text {PIC }}=$ growth rate $(\mu) \times$ cellular PIC content in batch cultures (e.g., Langer et al., 2006, 2009, 2012). Another is cellspecific calcite production (CP) (e.g., Poulton et al., 2013, 2014; Charalampopoulou et al., 2011, 2016), which is calculated by dividing $\mathrm{CP}$ by cell abundance. These two parameters are obviously related to the cellular PIC content or single-coccolith calcite content; however, they are not equivalent because both calcification rate and cell-specific $\mathrm{CP}$ are also strongly influenced by coccolithophore or the coccolith production rate. Hence, the following discussion is based on the coccolith biometry-related parameters, e.g., coccolith or coccosphere length, coccolith or coccosphere calcite content (weight).

\subsubsection{Nutrient and light}

The statistically significant correlation between the nutrient and mean DSL of E. huxleyi suggests that both nitrogen and phosphorus exert a positive influence on coccolith length. However, in nutrient-limited batch cultures, it has been shown that $E$. huxleyi morphology displayed divergent responses to different types of resource limitation; e.g., coccolith or coccosphere length or volume and/or calcite content deceased and increased under nitrogen- and phosphorus-limited conditions, respectively (Riegman et al., 2000; Müller et al., 2008, 2012; Oviedo et al., 2014). The increased coccolith or coccosphere size of E. huxleyi was also found in phosphorus-deficient mesocosm enclosures (Båtvik et al., 1997; Engel et al., 2005). The interpretation is that nitrogen and phosphorus are required for distinctly different cellular uses: nitrogen for biomass growth and phosphorus for cell division and organic maturity (e.g., Arrigo, 2005; Aloisi, 2015). Therefore, under nitrogen limitation, coccolithophores will produce smaller cells with a smaller-sized coccolith, and on the other hand, phosphorus limitation inhibits cell division, whereas biomass in cells still grows, leading to an increase in coccolith or coccosphere size (Müller et al., 2008, 2012). Back to the present case, the nutrient limitation theory indicates that nitrogen should be the main controlling factor on coccolith size. The positive relation of DSL and phosphorus may come from the high intercorrelation between the two types of nutrients (Pearson, $r=0.99$, $p<0.01$ ).

Nutrient is an important limiting factor in E. huxleyi growth (i.e., under laboratory culturing conditions); when 


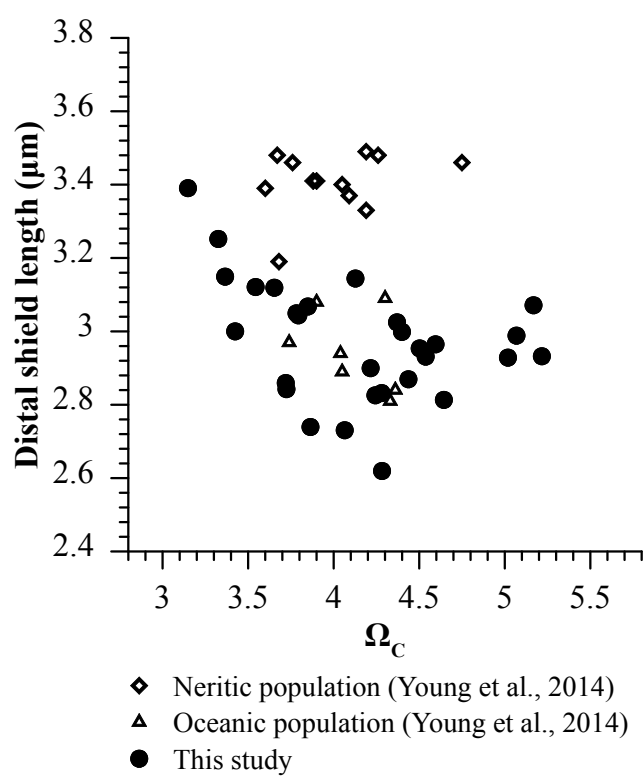

Figure 11. E. huxleyi type A distal shield length (DSL) in the South China Sea (black circles) with those in neritic populations (hollow diamonds) and oceanic populations (hollow triangles) in the North Sea (Young et al., 2014), plotted versus carbonate calcium saturation $\left(\Omega_{\mathrm{C}}\right)$.

nutrients are replete, E. huxleyi growth is fast (exponential phase), with fewer and smaller coccoliths per cell. When nutrients become limiting, E. huxleyi growth slows (stationary phase), and larger and multilayer coccospheres are produced (Gibbs et al., 2013). Besides nutrients, it is suggested that light should also be a limiting factor for $E$. huxleyi production and calcification in natural community (e.g., Poulton et al., 2007, 2010, 2014; Charalampopoulou et al., 2011). With a closer inspection of the DSL data, the largest coccoliths occurred at the deepest depths where nutrients were sufficient and light was insufficient, while within the E. huxleyi abundant depth coccoliths were relatively small (most remarkable at X3, F1, D9, I7, X5; Fig. 10a). Estimated from the monthly (June 2014) instantaneous PAR $\left(\sim 2000 \mu \mathrm{mol} \mathrm{m}^{-2} \mathrm{~s}^{-1}\right.$, ocean color AquaMODIS satellite) in the SCS, the PAR in the water column was about $200,<100$, and $20 \mu \mathrm{mol} \mathrm{m}^{-2} \mathrm{~s}^{-1}$ at $50(10 \%)$, $75(<5 \%)$, and $100 \mathrm{~m}(1 \%)$ depth, respectively. E. huxleyi growth is likely to be limited by light, although some authors have stated that light should not be regarded as a factor regulating phytoplankton growth in the oligotrophic SCS as the euphotic zone depth exceeds the MLD and nutricline throughout the year (Tseng et al., 2005; Wong et al., 2007). The higher half-saturation constants of E. huxleyi for light $\left(\sim 100 \mu \mathrm{mol} \mathrm{m}^{-2} \mathrm{~s}^{-1}\right.$ for E. huxleyi and $\sim 40 \mu \mathrm{mol} \mathrm{m}^{-2} \mathrm{~s}^{-1}$ for other phytoplankton groups; Tyrrell and Taylor, 1996) may support our statement that E. huxleyi growth is more light-dependent in the SCS. Here, we propose a simple schematic (Fig. 10b). (1) In the DCM layer, where light and nutrients are optimal for phytoplankton growth, E. huxleyi growth is fast and the species produces small-sized coccoliths. (2) In deeper waters, when nutrients are more sufficient but light is not available, E. huxleyi growth slows and the species produces larger-sized coccoliths. It has been reported that an E. huxleyi cell can produce higher-calcitecontent coccoliths with a lower growth rate in light-limited continuous cultures (Fritz and Balch, 1996; Fritz, 1999). That light limitation, in E. huxleyi cells, can prolong the G1 assimilation stage during which calcification takes place and will eventually increase cellular calcite content (Müller et al., 2008). Although coccolith formation is a light-dependent process, it does not seem to be impeded in the low-light conditions. This could be owing to the calcification having a lower light-saturated threshold than photosynthesis (Müller et al., 2008). (3) Above the nutricline, where light intensity is high and multi-nutrients are depleted, it is possible that E. huxleyi coccolith size is dependent on whether inorganic phosphorus is deficient or organic phosphorus compounds can be utilized, although we lack data to directly address either nutrient availability or coccolith biometry in these samples.

\subsubsection{Temperature}

Temperature is expected to be a critical factor for coccolithophore growth and cell size. An E. huxleyi strain isolated from Great Barrier Reef showed an optimal growth temperature at $25^{\circ} \mathrm{C}$ with the smallest cell size, while the growth rate and cell size became lower and bigger in parallel as the temperature was decreased to $10^{\circ} \mathrm{C}$ (Sorrosa et al., 2005). A recent culturing study (Saruwatari et al., 2016) has also shown that $E$. huxleyi strains of the morphotype B/C isolated from the Arctic Ocean grow faster and produce smaller coccoliths when temperature increases from 5 to $20^{\circ} \mathrm{C}$. However, contradictory results come from Rosas-Navarro et al. (2016), who have found that $E$. huxleyi (type A, strains isolated from North Pacific Ocean) produces the largest coccoliths within the optimal growth temperature of 20 to $25^{\circ} \mathrm{C}$. Apparently, these different patterns of $E$. huxleyi coccolith size may result from strain-specific or morphotype (ecotype) responses to temperature. In the present study, temperature was not found to correlate with E. huxleyi coccolith size from the statistical analysis (Table 3). One possible reason could be that the temperature profiles were to a large extent controlled by the eddy-related water-column structure (i.e., MLD), which may possibly mute the signal of their influences on $E$. huxleyi growth and size. Alternatively, as stated by Bach et al. (2012), temperature may exert little physiological influence on E. huxleyi size. In addition, the temperature at the investigated stations ranged from 18 to $25^{\circ} \mathrm{C}$ at depths from 100 to $50 \mathrm{~m}$, which is near the optimal growth temperature for many E. huxleyi strains ( 20 to $25^{\circ} \mathrm{C}$; Paasche, 2002; Sorrosa et al., 2005; Rosas-Navarro et al., 2016). That is, tem- 
perature may not be a limiting factor for E. huxleyi growth within the euphotic zone in the tropical SCS, apart from surface and/or near-surface waters where water temperatures are $>29^{\circ} \mathrm{C}$, above the growth optimum temperature range for this species (Rosas-Navarro et al., 2016).

\subsubsection{Carbonate chemistry}

Coccolithophores are thought to be sensitive indicators of carbonate chemistry, especially $\Omega_{\mathrm{C}}$ and $\left[\mathrm{CO}_{3}^{2-}\right]$ (e.g., Beaufort et al., 2011). Our results show that the mean DSL is inversely correlated with $\mathrm{pH}$ and $\Omega_{\mathrm{C}}$. Indeed, all the environmental data were significantly intercorrelated (Table 3), nearly all contributing to one principal component (PC-1, $76.59 \%$ of variance) (Table 3 ). That is, the environmental gradients in the water column are dependent on sampling depth. Importantly, in the data from the SCS the carbonate chemistry inversely mirrors the nutrient data, making it hard to distinguish its influence on coccolith morphology. Similarly, due to the high intercorrelation levels of all environmental variants in two transects in the Southern Ocean, carbonate chemistry does not seem to be the best interpretation for E. huxleyi cell-specific calcification (Charalampopoulou et al., 2016). Hence, it is not possible to directly infer that $E$. huxleyi coccolith size and carbonate chemistry have a simple cause and effect relationship in the SCS.

Here, our DSL results in the SCS were compared with those in the North Sea (Young et al., 2014) (Fig. 11). In the North Sea, E. huxleyi was also dominated by morphotype A (Young et al., 2014). While $\Omega_{C}$ in the two regions falls within a similar range, DSL shows a significant difference $(F=17.18, p<0.01)$. Young et al. (2014) have argued that E. huxleyi DSL differences relate to neritic and oceanic groups rather than to carbonate chemistry impacts. DSLs in our samples show no significant difference with those in the oceanic group ( $F=0.243, p=0.63$ ); however, they are significantly lower than those in the neritic group from Young et al. (2014) $(F=125.2, p<0.01)$ (Fig. 11). Hence, what causes the morphological distinction may be genotypic variation or an ecological effect (Bach et al., 2012). It is suggested that the changing environmental conditions can select for different coccolithophore strains, which indirectly influences the coccolith size and morphology (Bach et al., 2012). For example, different environmental provinces can shift from a community dominated by normally calcified $E$. huxleyi type A to one characterized by weakly calcified B/C on the Patagonian Shelf and in the Southern Ocean (Cubillos et al., 2007; Poulton et al., 2011). More heavily calcified morphotypes during low $\Omega_{\mathrm{C}}$ in winter may be responsible for the seasonal morphotype transition in the Bay of Biscay (Smith et al., 2012). Seasonal variability of E. huxleyi coccolith size has also been observed in the Aegean Sea, which may be due to genotypic or ecophenotypic variation (Triantaphyllou et al., 2010). Meier et al. (2014) found that mean coccolith weight peaked at the Rockall Plateau during Hein- rich event 11 , when $\Omega_{\mathrm{C}}$ and $\mathrm{pH}$ had minimum values. This could be due to a coccolith assemblage shift to more heavily calcified morphotypes in relation to oceanic frontal changes during this geological episode rather than the influences of carbonate chemistry (Meier et al., 2014). In conclusion, the ecological transition of assemblages may have a more dominant effect on coccolith morphology and/or cellular calcification not only in the present ocean but also in geological records.

\section{Conclusions}

In the South China Sea (SCS), the coccolithophore community corresponds to the tropical biogeographic zone, with many characteristic tropical species being present (e.g., Umbellosphaera irregularis, Florisphaera profunda). Coccol-

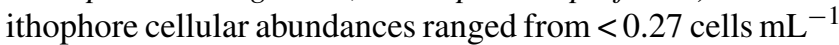
to 83.67 cells $\mathrm{mL}^{-1}$ across the SCS basin. Highest cell concentrations occurred in the deep chlorophyll maximum, with all of the coccolithophore community within the euphotic zone (i.e., above the depth where $1 \%$ of surface irradiance penetrates). Emiliania huxleyi (type A) was the numerically dominant species in the SCS during summer.

Water samples were divided into three groups according to the composition of their coccolithophore communities. Group 1, characterized by the presence of $U$. irregularis, preferred oligotrophic conditions; Group 2, dominated by $E$. huxleyi, had relative high coccolithophore cell abundances; and Group 3 contained lower photic species such as F. profunda. These coccolithophore communities through the water column showed strong vertical differentiation, with depth shifts in response to mesoscale eddy features along the $18^{\circ} \mathrm{N}$ section (Figs. 5, 8). Briefly, anticyclonic eddies were occupied with oligotrophic representative species, whereas coccolithophore assemblages in the cyclonic eddy were slightly productive.

Estimates of calcite concentrations in the upper water column based on coccosphere and coccolith calcite contents closely matched detached coccolith concentrations, highlighting their significant contribution to calcite standing stocks. Three key species (E. huxleyi, Gephyrocapsa oceanica, F. profunda) contributed roughly half (Fig. 7) of the surface ocean coccolith-calcite concentrations. Moreover, they had an increased contribution to deep-sea coccolith and calcite fluxes (Jin et al., unpublished), highlighting their importance for coccolith carbonate production in the SCS.

Biometric measurements of E. huxleyi coccoliths showed significant $(p<0.01)$ positive relationships with nutrient (nitrate, phosphate) concentrations and negative relationships with carbonate chemistry $\left(\mathrm{pH}, \Omega_{\mathrm{C}}\right)$ (Table 3$)$, although all of these environmental parameters were strongly correlated. It is suggested that light and nutrients are more likely to explain the E. huxleyi coccolith variations rather than carbonate chemistry. Larger-sized coccoliths for E. huxleyi are 
produced in deep and light-limited waters with a slow cell growth rate, while in optimal conditions (i.e., in deep chlorophyll maximum), they are likely to produce smaller-sized coccoliths with faster growth rates.

\section{The Supplement related to this article is available online at doi:10.5194/bg-13-4843-2016-supplement.}

Author contributions. Xiaobo Jin, Chuanlian Liu, and Alex J. Poulton designed the experiments and Xiaobo Jin carried them out. Chuanlian Liu was the supervisor of this project. Xiaobo Jin and Alex J. Poulton drafted and revised the manuscript. Nutrients and carbonate chemistry data were provided by Minhan Dai and Xianghui Guo.

Acknowledgements. This work is financed by the National Natural Science Foundation of China (grant nos. 91228204, 41376047). We are grateful to the cruise colleagues of R/V Dongfanghong II and the Ocean Carbon Group of Xiamen University. We are also grateful to R. B. Pearce, R. M. Sheward, and G. M. Fragoso for their assistance in light and scanning electron microscopy and to H. E. K. Smith for her assistance in statistical analysis (National Oceanography Centre). M. Wang and H. R. Zhang are thanked for their assistance in AVISO data compiling. A. J. Poulton would also like to acknowledge financial support from National Capability funding from the Natural Environmental Research Council. We also thank the anonymous reviewers for their constructive comments on the discussion paper.

Edited by: K. Suzuki

Reviewed by: two anonymous referees

\section{References}

Aloisi, G.: Covariation of metabolic rates and cell size in coccolithophores, Biogeosciences, 12, 4665-4692, doi:10.5194/bg-124665-2015, 2015.

Andruleit, H. and Rogalla, U.: Coccolithophores in surface sediments of the Arabian Sea in relation to environmental gradients in surface waters, Mar. Geol., 186, 505-526, 2002.

Andruleit, H., Stäger, S., Rogalla, U., and Čepek, P.: Living coccolithophores in the northern Arabian Sea: ecological tolerances and environmental control, Mar. Micropaleontol., 49, 157-181, 2003

Arrigo, K. R.: Marine microorganisms and global nutrient cycles, Nature, 437, 349-355, 2005.

Bach, L. T., Bauke, C., Meier, K. J. S., Riebesell, U., and Schulz, K. G.: Influence of changing carbonate chemistry on morphology and weight of coccoliths formed by Emiliania huxleyi, Biogeosciences, 9, 3449-3463, doi:10.5194/bg-9-3449-2012, 2012.

Bach, L. T., Riebesell, U., Gutowska, M. A., Federwisch, L., and Schulz, K. G.: A unifying concept of coccolithophore sensitivity to changing carbonate chemistry embedded in an ecological framework, Prog. Oceanogr., 135, 125-138, 2015.
Balch, W. M., Holligan, P. M., Ackleson, S. G., and Voss, K. J.: Biological and optical properties of mesoscale coccolithophore blooms in the Gulf of Maine, Limnol. Oceanogr., 36, 629-643, 1991.

Balch, W. M., Drapeau, D. T., Bowler, B. C., Lyczkowski, E. R., Booth, E. S., and Alley, D.: The contribution of coccolithophores to the optical and inorganic carbon budgets during the Southern Ocean Gas Exchange Experiment: New evidence in support of the "Great Calcite Belt" hypothesis, J. Geophys. Res.-Ocean., 116, C00F06, doi:10.1029/2011JC006941, 2011.

Balch, W. M., Drapeau, D. T., Bowler, B. C., Lyczkowski, E. R., Lubelczyk, L. C., Painter, S. C., and Poulton, A. J.: Surface biological, chemical, and optical properties of the Patagonian Shelf coccolithophore bloom, the brightest waters of the Great Calcite Belt, Limnol. Oceanogr., 59, 1715-1732, 2014.

Båtvik, H., Heimdal, B. R., Fagerbakke, K. M., and Green, J. C.: Effects of unbalanced nutrient regime on coccolith morphology and size in Emiliania huxleyi (Prymnesiophyceae), Eur. J. Phycol., 32, 155-165, 1997.

Beaufort, L. and Heussner, S.: Coccolithophorids on the continental slope of the Bay of Biscay-production, transport and contribution to mass fluxes, Deep-Sea Res. Pt. II, 46, 2147-2174, 1999.

Beaufort, L., Couapel, M., Buchet, N., Claustre, H., and Goyet, C.: Calcite production by coccolithophores in the south east Pacific Ocean, Biogeosciences, 5, 1101-1117, doi:10.5194/bg-5-11012008, 2008.

Beaufort, L., Probert, I., Garidel-Thoron, T., Bendif, E. M., RuizPino, D., Metzl, N., Goyet, C., Buchet, N., Coupel, P., Grelaud, M., Rost, B., Rickaby, E. M., and Vargas, C.: Sensitivity of coccolithophores to carbonate chemistry and ocean acidification, Nature, 476, 80-83, 2011.

Boeckel, B. and Baumann, K. H.: Vertical and lateral variations in coccolithophore community structure across the subtropical frontal zone in the South Atlantic Ocean, Mar. Micropaleontol., 67, 255-273, 2008.

Bollmann, J., Cortés, M. Y., Haidar, A. T., Brabec, B., Close, A., Hofmann, R., Palma, S., Tupas, L., and Thierstein, H. R.: Techniques for quantitative analyses of calcareous marine phytoplankton, Mar. Micropaleontol., 44, 163-185, 2002.

Charalampopoulou, A., Poulton, A. J., Tyrrell, T., and Lucas, M. I.: Irradiance and $\mathrm{pH}$ affect coccolithophore community composition on a transect between the North Sea and the Arctic Ocean, Mar. Ecol. Prog. Ser., 431, 25-43, 2011.

Charalampopoulou, A., Poulton, A. J., Bakker, D. C. E., Lucas, M. I., Stinchcombe, M. C., and Tyrrell, T.: Environmental drivers of coccolithophore abundance and calcification across Drake Passage (Southern Ocean), Biogeosciences Discuss., doi:10.5194/bg-2016-139, in review, 2016.

Chen, C. C., Shiah, F. K., Chung, S. W., and Liu, K. K.: Winter phytoplankton blooms in the shallow mixed layer of the South China Sea enhanced by upwelling, J. Mar. Syst., 59, 97-110, 2006.

Chen, G., Hou, Y., and Chu, X.: Mesoscale eddies in the South China Sea: Mean properties, spatiotemporal variability, and impact on thermohaline structure, J. Geophys. Res.-Ocean., 116, C06018, doi:10.1029/2010JC006716, 2011.

Chen, Y. L.: Spatial and seasonal variations of nitrate-based new production and primary production in the South China Sea, Deep-Sea Res. Pt. I, 52, 319-340, 2005. 
Chen, Y. L., Chen, H. Y., and Chung, C. W.: Seasonal variability of coccolithophore abundance and assemblage in the northern South China Sea, Deep-Sea Res. Pt. II, 54, 1617-1633, 2007a.

Chen, Y. L., Chen, H. Y., Lin, I. I., Lee, M. A., and Chang, J.: Effects of cold eddy on phytoplankton production and assemblages in Luzon Strait bordering the South China Sea, J. Oceanogr., 63, 671-683, 2007b.

Cheng, X. R. and Wang, P. X.: Controlling factors of coccolith distribution in surface sediments of the China seas: marginal sea nannofossil assemblages revisited, Mar. Micropalontol., 32, 155$172,1997$.

Clarke, K. R. and Warwick, R. M.: Change in marine communities: an approach to statistical analysis and interpretation, 2nd Edn. PRIMER-E, Plymouth, 2001

Cokacar, T., Oguz, T., and Kubilay, N.: Satellite-detected early summer coccolithophore blooms and their interannual variability in the Black Sea, Deep-Sea Res. Pt. I, 51, 1017-1031, 2004.

Cook, S. S., Whittock, L., Wright, S. W., and Hallegraeff, G. M.: Photosynthetic pigment and genetic differences between two Southern Ocean morphotypes of Emiliania huxleyi (Haptophyta), J. Phycol., 47, 615-626, 2011.

Cubillos, J. C., Wright, S. W., Nash, G., De Salas, M. F., Griffiths, B., Tilbrook, B., Poisson, A., and Hallegraeff, G. M.: Calcification morphotypes of the coccolithophorid Emiliania huxleyi in the Southern Ocean: changes in 2001 to 2006 compared to historical data, Mar. Ecol. Prog. Ser., 348, 47-54, 2007.

Daniels, C. J., Sheward, R. M., and Poulton, A. J.: Biogeochemical implications of comparative growth rates of Emiliania huxleyi and Coccolithus species, Biogeosciences, 11, 6915-6925, doi:10.5194/bg-11-6915-2014, 2014.

Dickson, A. G., Sabine, C. L., and Christian, J. R.: Guide to best practices for ocean $\mathrm{CO}_{2}$ measurements, PICES Special Publication 3, 191 pp. 2007.

Eden, B. R., Steinberg, D. K., Goldthwait, S. A., and McGillicuddy, D. J.: Zooplankton community structure in a cyclonic and modewater eddy in the Sargasso Sea, Deep-Sea Res. Pt. I, 56, 17571776, 2009.

Engel, A., Zondervan, I., Aerts, K., Beaufort, L., Benthien, A., Chou, L., Delille, B., Gattuso, J., Harlay, J., Heemann, C., Hoffmann, L., Jacquet, S., Nejstgaard, J., Pizay, M., Rochelle-Newall, E., Schneider, U., Terbrueggen, A., and Riebesell, U.: Testing the direct effect of $\mathrm{CO}_{2}$ concentration on a bloom of the coccolithophorid Emiliania huxleyi in mesocosm experiments, Limnol. Oceanogr., 50, 493-507, 2005.

Fernando, A. G. S., Peleo-Alampay, A. M., and Wiesner, M. G.: Calcareous nannofossils in surface sediments of the eastern and western South China Sea, Mar. Micropaleontol., 66, 1-26, 2007.

Frada, M., Young, J., Cachão, M., Lino, S., Martins, A., Narciso, Á., Probet, I., and de Vargas, C.: A guide to extant coccolithophores (Calcihaptophycidae, Haptophyta) using light microscopy, J. Nannoplank. Res., 31, 58-112, 2010.

Fritz, J. J. and Balch, W. M.: A light-limited continuous culture study of Emiliania huxleyi: determination of coccolith detachment and its relevance to cell sinking, J. Exp. Mar. Biol. Ecol., 207, 127-147, 1996.

Fritz, J. J.: Carbon fixation and coccolith detachment in the coccolithophore Emiliania huxleyi in nitrate-limited cyclostats, Mar. Biol., 133, 509-518, 1999.
Gibbs, S. J., Poulton, A. J., Bown, P. R., Daniels, C. J., Hopkins, J., Young, J. R., Jones, H. L., Thiemann, G. J., O’Dea, S. A., and Newsam, C.: Species-specific growth response of coccolithophores to Palaeocene-Eocene environmental change, Nat. Geosci., 6, 218-222, 2013.

Hagino, K., Okada, H., and Matsuoka, H.: Spatial dynamics of coccolithophore assemblages in the Equatorial Western-Central Pacific Ocean, Mar. Micropaleontol., 39, 53-72, 2000.

Hagino, K., Okada, H., and Matusoka, H.: Coccolithophore assemblages and morphotypes of Emilania huxleyi in the boundary zone between the cold Oyashio and warm Kuroshio currents off the coast of Japan, Mar. Micropaleontol., 55, 119-147, 2005.

Hagino, K., Bendif, E. L., Young, J. R., Kogame, K., Probert, I., Takano, Y., Horiguchi, T., des Vargas, C., and Okada, H.: New evidence for morphological and genetic variation in the cosmopolitan coccolithophore Emiliania huxleyi (prymnesiophyceae) from the COX1B-ATP4 genes, J. Phycol., 47, 11641176, 2011.

Hammer, Ø., Harper, D. A. T., and Ryan, P. D.: PAST: Paleontological Statistics Software Package for education and data analysis, Palaeontolia Electronica, 4, 9 pp., 2001.

Henderiks, J.: Coccolithophore size rules - reconstructing ancient cell geometry and cellular calcite quota from fossil coccoliths, Mar. Micropaleontol., 67, 143-154, 2008.

Henderiks, J., Winter, A., Elbrächter, M., Feistel, R., Van der Plas, A., Nausch, G., and Barlow, R.: Environmental controls on Emiliania huxleyi morphotypes in the Benguela coastal upwelling system (SE Atlantic), Mar. Ecol. Prog. Ser., 448, 51-66, 2012.

Hu, J., Gan, J., Sun, Z., Zhu, J., and Dai, M. H.: Observed thre-dimensional structure of a cold eddy in the southwestern South China Sea, J. Geophys. Res.-Ocean., 116, , C05016, doi:10.1029/2010JC006810, 2011.

Huang, B., Hu, J., Xu, H., Cao, Z., and Wang, D.: Phytoplankton community at warm eddies in the northern South China Sea in winter 2003/2004, Deep-Sea Res. Pt. II, 57, 1792-1798, 2010.

Iglesias-Rodriguez, M. D., Halloran, P. R., Rickaby, R. E. M., Hall, I. R., Colmenero-Hidalgo, E., Gittins, J. R., Green, D. R. H., Armbrust, E. V., and Boessenkool, K. P.: Phytoplankton calcification in a high- $\mathrm{CO}_{2}$ world, Science, 320, 336-340, 2008.

Jaya, B. N., Hoffmann, R., Kirchlechner, C., Dehm, G., Scheu, C., and Langer, G.: Coccospheres confer mechanical protection: New evidence for and old hypothesis, Acta Biomater., in press, doi:10.1016/j.actbio.2016.07.036, 2016.

Jordan, R. W.: Coccolithophores, in: Eukaryotic Microbes, edited by: Schaechter, M., Elsevier, 235-247, 2012.

Knappertsbusch, M. and Brummer, G. J. A.: A sediment trap investigation of sinking coccolithophorids in the North Atlantic, Deep-Sea Res. Pt. I, 42, 1083-1109, 1995.

Langer, G., Geisen, M., Baumann, K. H., Kläs, J., Riebesell, U., Thoms, S., and Young, J. R.: Species-specific responses of calcifying algae to changing seawater carbonate chemistry, Geochem. Geophy. Geosys., 7, Q09006, doi:10.1029/2005GC001227, 2006.

Langer, G., Nehrke, G., Probert, I., Ly, J., and Ziveri, P.: Strain-specific responses of Emiliania huxleyi to changing seawater carbonate chemistry, Biogeosciences, 6, 2637-2646, doi:10.5194/bg-6-2637-2009, 2009. 
Langer, G., Oetjen, K., and Brenneis, T.: Calcification of Calcidiscus leptoporus under nitrogen and phosphorus limitation, J. Exp. Mar. Biol. Ecol., 413, 131-137, 2012.

Lin, I. I., Lien, C. C., Wu, C. R., Wong, G. T., Huang, C. W., and Chiang, T. L.: Enhanced primary production in the oligotrophic South China Sea by eddy injection in spring, Geophys. Res. Lett., 37, , L16602, doi:10.1029/2010GL043872, 2010.

Liu, K. K., Chao, S. Y., Shaw, P. T., Gong, G. C., Chen, C. C., and Tang, T. Y.: Monsoon-forced chlorophyll distribution and primary production in the South China Sea: observations and a numerical study, Deep-Sea Res. Pt. I, 49, 1387-1412, 2002.

Malinverno, E.: Morphological variability within the genus $\mathrm{Cal}$ ciosolenia (coccolithophorids) from the eastern Mediterranean Sea, Micropaleontology, 50, 81-91, 2004.

McGillicuddy, D. J., Anderson, L. A., Bates, N. R., Bibby, T., Buesseler, K. O., Carlson, C. A., Davis, C. S., Ewart, C., Falkowski, P. G., Goldthewait, S. A., Hansell, D. A., Jenkins, W. J., Johnson, R., Kosnyrev, V. K., Ledwell, J. R., Li, Q. P., Siegel, D. A., and Steinberg, D. K.: Eddy/wind interactions stimulate extraordinary mid-ocean plankton blooms, Science, 316, 1021-1026, 2007.

Meier, K. J. S., Berger, C., and Kinkel, H.: Increasing coccolith calcification during $\mathrm{CO}_{2}$ rise of the penultimate deglaciation (Termination II), Mar. Micropaleontol., 112, 1-12, 2014.

Meyer, J. and Riebesell, U.: Reviews and Syntheses: Responses of coccolithophores to ocean acidification: a meta-analysis, Biogeosciences, 12, 1671-1682, doi:10.5194/bg-12-1671-2015, 2015.

Mullin, M. M.: Biomasses of large-celled phytoplankton and their relation to the nitricline and grazing in the California Current system off Southern California, 1994-1996, California Cooperative Oceanic Fisheries Investigations Report, 117-123, 1998.

Müller, M., Antia, A., and LaRoche, J.: Influence of cell cycle phase on calcification in the coccolithophore Emiliania huxleyi, Limnol. Oceanogr., 53, 506-512, 2008.

Müller, M. N., Beaufort, L., Bernard, O., Pedrotti, M. L., Talec, A., and Sciandra, A.: Influence of $\mathrm{CO}_{2}$ and nitrogen limitation on the coccolith volume of Emiliania huxleyi (Haptophyta), Biogeosciences, 9, 4155-4167, doi:10.5194/bg-9-4155-2012, 2012.

Ning, X.R., Chai, F., Xue, H., Cai, Y., Liu, C., and Shi, J.: Physicaloceanographic coupling influencing phytoplankton and primary production in the South China Sea, J. Geophys. Res.-Ocean., 109, C10005, doi:10.1029/2004JC002365, 2004.

O’Dea, S. A., Gibbs, S. J., Bown, P. R., Young, J. R., Poulton, A. J., Newsam, C., and Wilson, P. A.: Coccolithophore calcification response to past ocean acidification and climate change, Nat. Commun., 5, 5363, doi:10.1038/ncomms6363, 2014.

Okada, H. and Honjo, S.: Distribution of coccolithophores in marginal seas along the western Pacific Ocean and in the Red Sea, Mar. Biol., 31, 271-285, 1975.

Oviedo, A. M., Langer, G., and Ziveri, P.: Effect of phosphorus limitation on coccolith morphology and element ratios in Mediterranean strains of the coccolithophore Emiliania huxleyi, J. Exp. Mar. Biol. Ecol., 459, 105-113, 2014.

Paasche, E.: A review of the coccolithophorid Emiliania huxleyi (Prymnesiophyceae), with particular reference to growth, coccolith formation, and calcification-photosynthesis interactions, Phycologia, 40, 503-529, 2002.

Painter, S. C., Poulton, A. J., Allen, J. T., Pidcock, R., and Balch, W. M.: The COPAS'08 expedition to the Patagonian Shelf: Physical and environmental conditions during the 2008 coccolithophore bloom, Cont. Shelf Res., 30, 1907-1923, 2010.

Pierrot, D. E., Lewis, E., and Wallace, D. W. R.: MS Excel program developed for $\mathrm{CO}_{2}$ system calculations. ORNL/CDIAC105a, Carbon Dioxide Information Analysis Centre, Oak Ridge National Laboratory, US Department of Energy, Oak Ridge, TN, 2006.

Poulton, A. J., Sanders, R., Holligan, P. M., Stinchcombe, M. C., Adey, T. R., Brown, L., and Chamberlain, K.: Phytoplankton mineralization in the tropical and subtropical Atlantic Ocean, Global Biogeochem. Cy., 20, GB4002, doi:10.1029/2006GB002712, 2006.

Poulton, A. J., Adey, T. R., Balch, W. M., and Holligan, P. M.: Relating coccolithophore calcification rates to phytoplankton community dynamics: regional differences and implications for carbon export, Deep-Sea Res. Pt. II, 54, 538-557, 2007.

Poulton, A. J., Charalampopoulou, A., Young, J. R., Tarran, G. A., Lucas, M. I., and Quartly, D.: Coccolithophore dynamics in nonconditions during late summer in the central Iceland Basin (JulyAugust 2007), Limnol. Oceanogr., 55, 1601-1613, 2010.

Poulton, A. J., Young, J. R., Bates, N. R., and Balch, W. M.: Biometry of detached Emiliania huxleyi coccoliths along the Patagonian Shelf, Mar. Ecol. Prog. Ser., 443, 1-17, 2011.

Poulton, A. J., Painter, S .C., Young, J. R., Bates, N. R., Bowler, B., Drapeau, D., Lyczsckowski, E., and Balch, W. M.: The 2008 Emiliania huxleyi bloom along the Patagonian Shelf: ecology, biogeochemistry, and cellular calcification, Global Biogeochem. Cy., 27, 1023-1033, 2013.

Poulton, A. J., Stinchcombe, M. C., Achterberg, E. P., Bakker, D. C. E., Dumousseaud, C., Lawson, H. E., Lee, G. A., Richier, S., Suggett, D. J., and Young, J. R.: Coccolithophores on the northwest European shelf: calcification rates and environmental controls, Biogeosciences, 11, 3919-3940, doi:10.5194/bg-11-39192014, 2014.

Raitsos, D. E., Lavender, S. J., Pradhan, Y., Tyrrell, T., Reid, P. C., and Edwards, M.: Coccolithophore bloom size variation in response to the regional environment of the subarctic North Atlantic, Limnol. Oceanogr., 51, 2122-2130, 2006.

Riebesell, U., Zondervan, I., Rost, B., Tortell, P. D., Zeebe, R. E., and Morel, F. M. M.: Reduced calcification of marine plankton in response to increased atmospheric $\mathrm{CO}_{2}$, Nature, 407, 364-367, 2000.

Riebesell, U. and Tortell, P. D.: Effects of ocean acidification on pelagic organisms and ecosystems, Ocean acidification, Oxford University Press, Oxford, 99-121, 2011.

Riegman, R., Stolte, W., Noordeloos, A. A., and Slezak, D.: Nutrient uptake and alkaline phosphatase (EC $3: 1: 3: 1$ ) activity of Emiliania huxleyi (Prymnesiophyceae) during growth under $\mathrm{N}$ and $\mathrm{P}$ limitation in continuous cultures, J. Phycol., 36, 87-96, 2000.

Rosas-Navarro, A., Langer, G., and Ziveri, P.: Temperature affects the morphology and calcification of Emiliania huxleyi strains, Biogeosciences, 13, 2913-2926, doi:10.5194/bg-13-2913-2016, 2016.

Saavedra-Pellitero, M., Baumann, K. H., Flores, J. A., and Gersonde, R.: Biogeographic distribution of living coccolithophores in the Pacific sector of the Southern Ocean, Mar. Micropaleontol., 109, 1-20, 2014. 
Saruwatari, K., Satoh, M., Harada, N., Suzuki, I., and Shiraiwa, Y.: Change in coccolith size and morphology due to response to temperature and salinity in coccolithophore Emiliania huxleyi (Haptophyta) isolated from the Bering and Chukchi seas, Biogeosciences, 13, 2743-2755, doi:10.5194/bg-13-2743-2016, 2016.

Schlitzer, R.: Ocean Data View, http://odv.awi.de, 2015.

Shih, Y. Y., Hung, C. C., Gong, G. C., Chung, W. C., Wang, Y. H., Lee, I. H., Chen, K. S., and Ho, C. Y.: Enhanced Particulate Organic Carbon Export at Eddy Edges in the Oligotrophic Western North Pacific Ocean, PloS one, 10, e0131538, doi:10.1371/journal.pone.0131538, 2015.

Smith, H. E. K., Tyrrell, T., Charalampopoulou, A., Dumousseaud, C., Legge, O. J., Birchenough, S., Petit, L. R., Garley, R., Herman,M. C., Sagoo, N., Daniels, C. J., Achterberg, E., and Hydes, D. J.: Predominance of heavily calcified coccolithophores at low $\mathrm{CaCO}_{3}$ saturation during winter in the Bay of Biscay, P. Natl. Acad. Sci., 109, 8845-8849, 2012.

Sorrosa, J. M., Satoh, M., and Shiraiwa, Y.: Low temperature stimulates cell enlargement and intracellular calcification of coccolithophorids, Mar. Biotechnol., 7, 128-133, 2005.

Sprengel, C., Baumann, K .H., and Neuer, S.: Seasonal and interannual variation of coccolithophore fluxes and species composition in sediment traps north of Gran Canaria $\left(29^{\circ} \mathrm{N}, 15^{\circ} \mathrm{W}\right)$, Mar. Micropaleontol., 39, 157-178, 2000.

Sprengel, C., Baumann, K. H., Henderiks. J., Henrich, R., and Neuer, S.: Modern coccolithophore and carbonate sedimentation along a productivity gradient in the Canary Islands region: seasonal export production and surface accumulation rates, DeepSea Res. Pt. II, 49, 3577-3598, 2002.

Sun, J., An. B. Z., Dai. M. H., and Li. T. G.: Living coccolithophores in the western South China Sea in summer 2007, Oceanol. Limnol. Sin., 42, 170-178, 2011 (in Chinese).

Triantaphyllou, M., Dimiza, M., Krasakopoulou, E., Malinverno, E., Lianou, V., and Souvermezoglou, E.: Seasonal variation in Emiliania huxleyi coccolith morphology and calcification in the Aegean Sea (Eastern Mediterranean), Geobios, 43, 99-110, 2010.

Tseng, C. M., Wong, G. T., Lin, I. I., Wu, C. R., and Liu, K. K.: A unique seasonal pattern in phytoplankton biomass in lowwaters in the South China Sea, Geophys. Res. Lett., 32, , L08608, doi:10.1029/2004GL022111, 2005.

Tyrrell, T. and Taylor, A. H.: A modelling study of Emiliania huxleyi in the NE Atlantic, J. Mar. Syst., 9, 83-112, 1996.

Wang, G., Su, J., and Chu, P. C.: Mesoscale eddies in the South China Sea observed with altimeter data, Geophys. Res. Lett., 30, 2121, doi:10.1029/2003GL01853, 2003.

Wang, L., Huang, B., Chiang, K. P., Liu, X., Chen, B., Xie, Y., $\mathrm{Xu}$, Y., Hu, J., and Dai, M.: Physical-Biological Coupling in the Western South China Sea: The Response of Phytoplankton Community to a Mesoscale Cyclonic Eddy, PloS one, 11, e0153735, doi:10.1371/journal.pone.0153735, 2016.
Wang, P., Li, Q., and Li, C. F.: Geology of the China Seas, Elsevier, 2014.

Wei, J. W.: Variability in beam attenuation and the suspended particles in the West Philippine Sea, PHD thesis in Chinese Academy of Sciences, 2005 (in Chinese).

Winter, A., Jordan, R. C., and Roth, P. H.: Biogeography of living coccolithophores in ocean waters, in Coccolithophores, edited by: Winter, A. and Siesser, W. G., Cambridge University Press, 1994.

Wong, G. T., Ku, T. L., Mulholland, M., Tseng, C. M., and Wang, D. P.: The South East Asian time-series study (SEATS) and the biogeochemistry of the South China Sea - an overview, DeepSea Res. Pt. II, 54, 1434-1447, 2007.

Xie, S. P., Xie, Q., Wang, D., and Liu, W. T.: Summer upwelling in the South China Sea and its role in regional climate variations, J. Geophys. Res.-Ocean., 108, 3261, doi:10.1029/2003JC001867, 2003.

Xiu, P. and Chai, F.: Modeled biogeochemical responses to mesoscale eddies in the South China Sea, J. Geophys. Res.Ocean., 116, C10006, doi:10.1029/2010JC006800, 2011.

Yan, X. H., Ho, C. R., Zheng, Q., and Klemas, V.: Temperature and size variabilities of the Western Pacific Warm Pool, Science, 258, 1643-1645, 1992.

Young, J. R.: Functions of coccoliths. In Coccolithophores, edited by: Winter, A. and Siesser, W. G., Cambridge University Press, 1994.

Young, J. R. and Ziveri, P.: Calculation of coccolith volume and it use in calibration of carbonate flux estimates, Deep-Sea Res. Pt. II, 47, 1679-1700, 2000.

Young, J. R., Geisen, M., Cros, L., Kleijne, A., Sprengel, C., Probert, I., and Østergaard, J.: A guide to extant coccolithophore taxonomy, International Nannoplankton Association, 2003.

Young, J. R., Poulton, A. J., and Tyrrell, T.: Morphology of Emiliania huxleyi coccoliths on the northwestern European shelf - is there an influence of carbonate chemistry?, Biogeosciences, 11, 4771-4782, doi:10.5194/bg-11-4771-2014, 2014.

Zhou, K. B., Dai, M. H., Kao, S. J., Wang, L., Xiu, P., Chai, F., Tian, J. W., and Liu, Y.: Apparent enhancement of ${ }^{234}$ Th-based particle export associated with anticyclonic eddies, Earth Planet Sci. Lett., 381, 198-209, 2013.

Ziveri, P., de Bernardi, B., Baumann, K. H., Stoll, H. M., and Mortyn, P. G.: Sinking of coccolith carbonate and potential contribution to organic carbon ballasting in the deep ocean, DeepSea Res. Pt. II, 54, 659-675, 2007. 